\section{ENVIRONMENTAL}

RESTORATION

PROGRAM

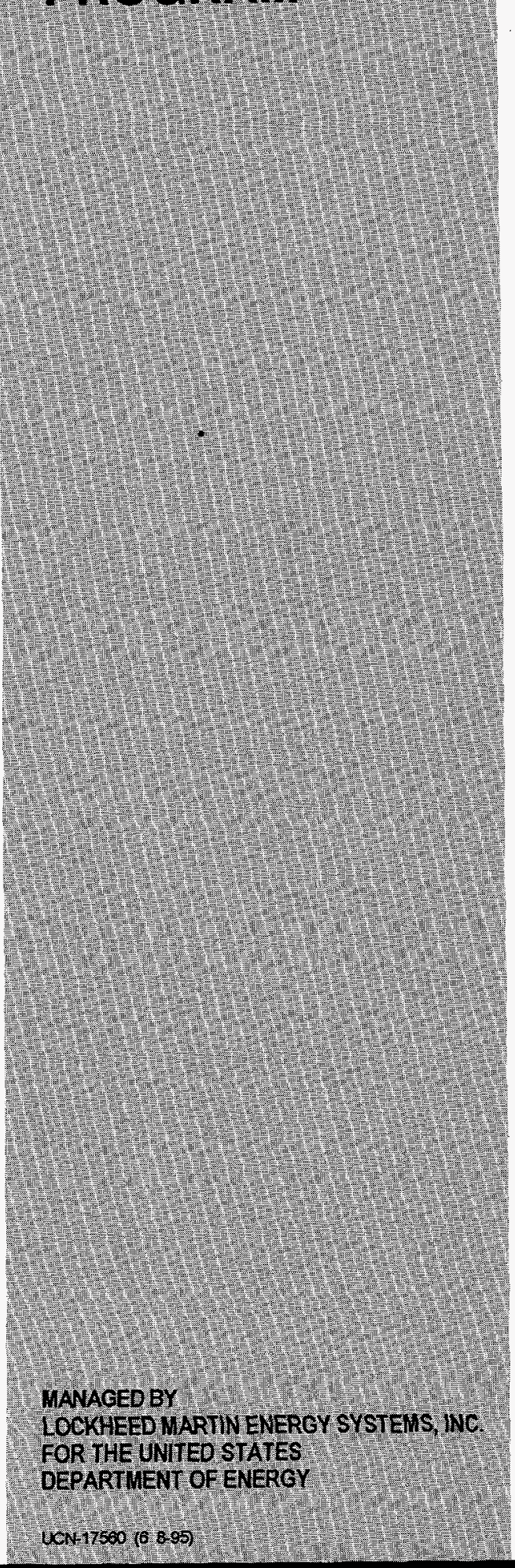

\section{Final Deactivation Report on the Radioisotope Production Lab-D, Building 3031, at Oak Ridge National Laboratory, Oak Ridge, Tennessee}
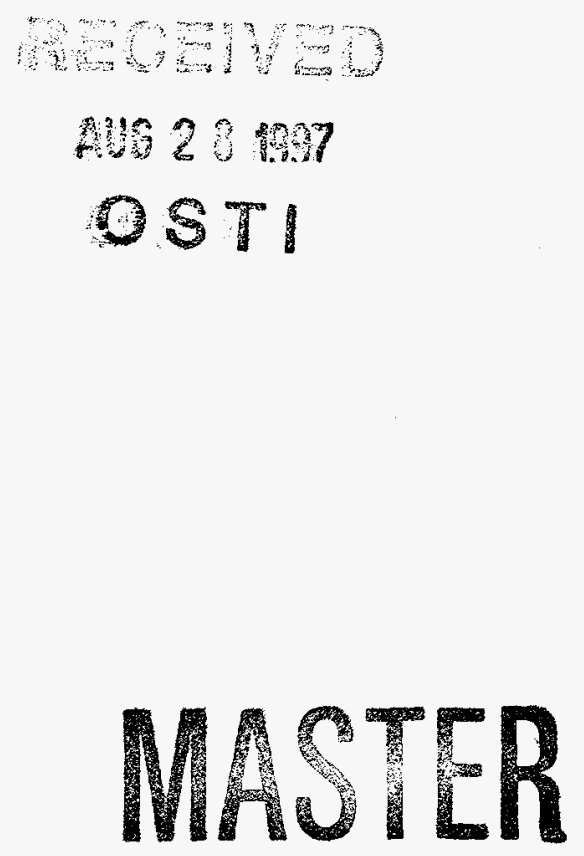

This document has been approved by the ORNL Technical Information Office for release to the public. Date: 8/12/97

ENERGY SYSTEMS

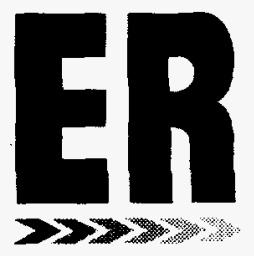



ORNL/ER-409

\title{
Final Deactivation Report on the Radioisotope Production Lab-D, Building 3031, at Oak Ridge National Laboratory, Oak Ridge, Tennessee
}

Date Issued-August 1997

DISTRIBUTION OF THIS DOGUMENT IS UNLIMITED

Prepared for the

U.S. Department of Energy

Office of Environmental Management

under budget and reporting code EW 20

Environmental Management Activities at

OAK RIDGE NATIONAL LABORATORY

Oak Ridge, Tennessee 37831

managed by

LOCKHEED MARTIN ENERGY SYSTEMS, INC.

for the

U.S. DEPARTMENT OF ENERGY

under contract DE-AC05-84OR21400

\section{DISCLAIMER}

\begin{abstract}
This report was prepared as an account of work sponsored by an agency of the United States Government. Neither the United States Government nor any agency thereof, nor any of their employees, makes any warranty, express or implied, or assumes any legal liability or responsibility for the accuracy, completeness, or usefulness of any information, apparatus, product, or process disclosed, or represents that its use would not infringe privately owned rights. Reference herein to any specific commercial product, process, or service by trade name, trademark, manufacturer, or otherwise does not necessarily constitute or imply its endorsement, recommendation, or favoring by the United States Government or any agency thereof. The views and opinions of authors expressed herein do not necessarily state or reflect those of the United States Government or any agency thereof.
\end{abstract}





\section{DISCLAMMER}

Portions of this document may be illegible in electronic image products. Images are produced from the best available original document. 



\section{PREFACE}

This is the Final Deactivation Report on the Radioisotope Production Lab-D, Building 3031, at Oak Ridge National Laboratory, Oak Ridge, Tennessee (ORNL/ER-409). Although this element of work is not part of the Comprehensive Environmental Response, Compensation, and Liability Act of 1980, it was accomplished in accordance with the substantive requirements of the Act. This work was performed under Work Breakdown Structure 1.6.6.2.10.02 (Activity Data Sheet 6504IS, "Isotopes Facilities Deactivation Project"). This document provides the Eñvironmental Management and Enrichment Facilities Program with the final report on the deactivation of Bldg. 3031. 



\section{CONTENTS}

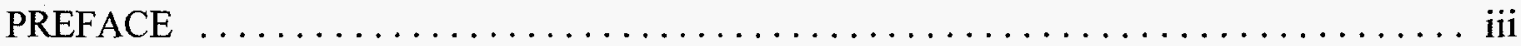

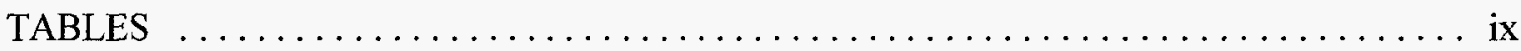

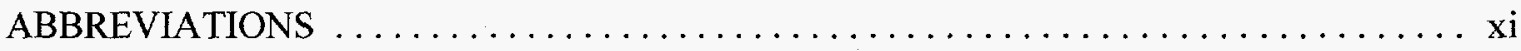

DEFINITIONS $\ldots \ldots \ldots \ldots \ldots \ldots \ldots \ldots \ldots \ldots \ldots \ldots \ldots \ldots \ldots \ldots \ldots \ldots \ldots \ldots \ldots \ldots \ldots \ldots \ldots$

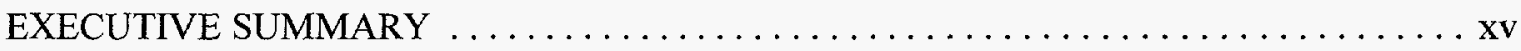

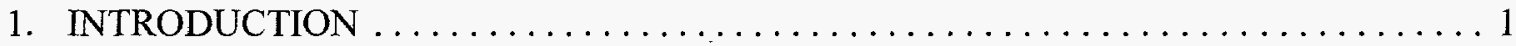

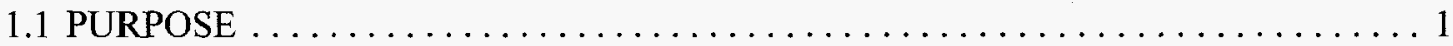

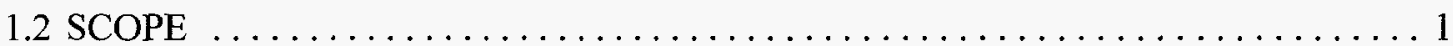

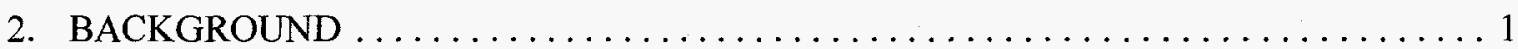

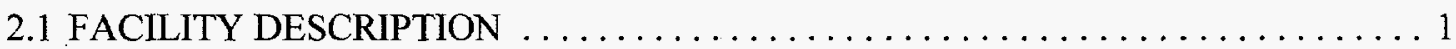

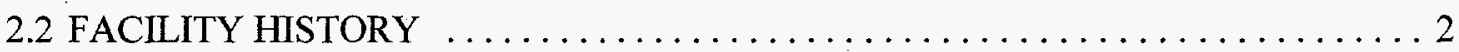

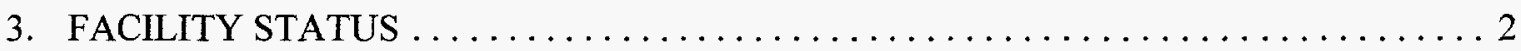

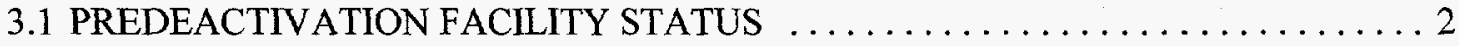

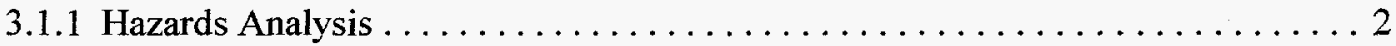

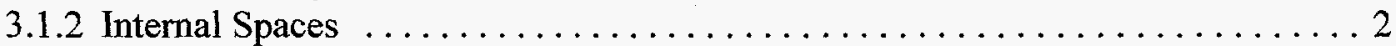

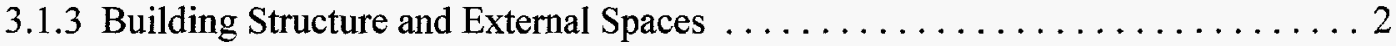

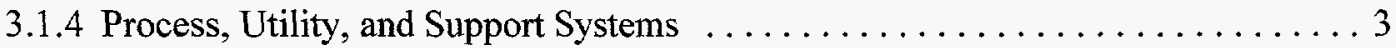

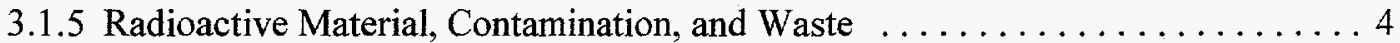

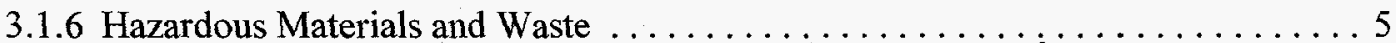

3.2 POSTDEACTIVATION FACILITY STATUS $\ldots \ldots \ldots \ldots \ldots \ldots \ldots \ldots \ldots \ldots \ldots \ldots \ldots \ldots$

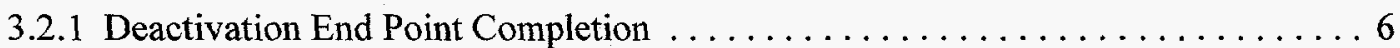

3.2 .2 Hazards Analysis . . . . . . . . . . . . . . . . . . . . . . . . 6

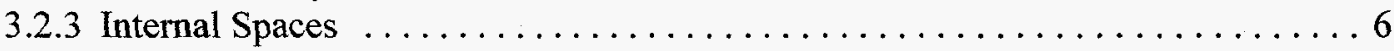

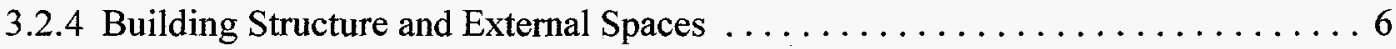

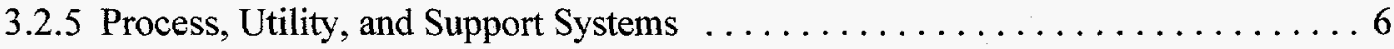

3.2.6 Radioactive Material, Contamination, and Waste $\ldots \ldots \ldots \ldots \ldots \ldots \ldots$

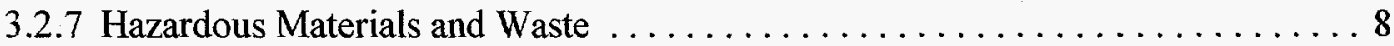

4. BUILDING 3031 DEACTIVATION ACTIVITIES $\ldots \ldots \ldots \ldots \ldots \ldots \ldots \ldots \ldots \ldots$

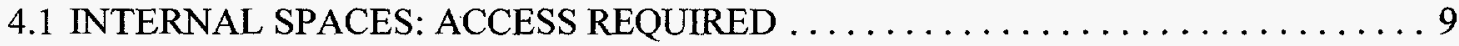

4.1 .1 General Areas . . . . . . . . . . . . . . . . . . . . . . . . . 9

4.2 INTERNAL SPACES: NO ACCESS REQUIRED $\ldots \ldots \ldots \ldots \ldots \ldots \ldots \ldots$

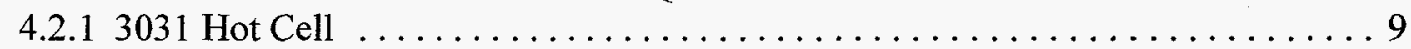

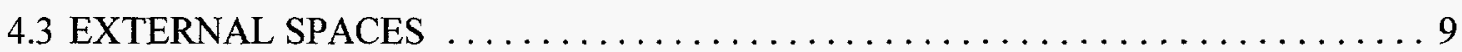

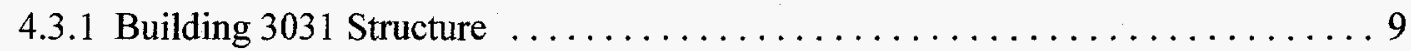

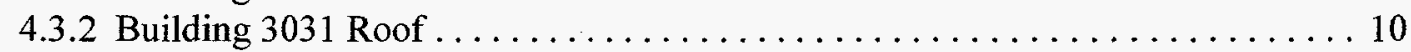

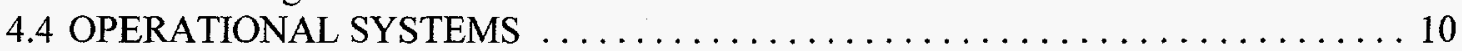

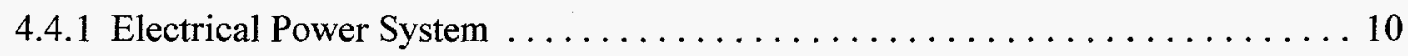




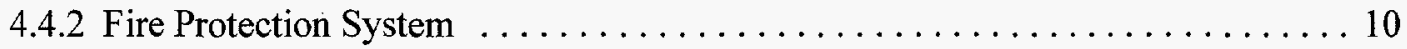

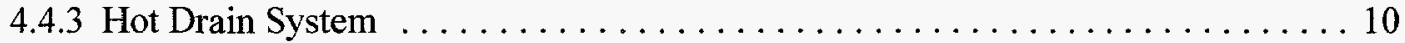

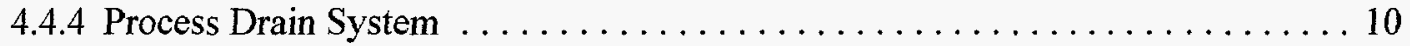

4.4 .5 Central Ventilation System . . . . . . . . . . . . . . . . . . . 10

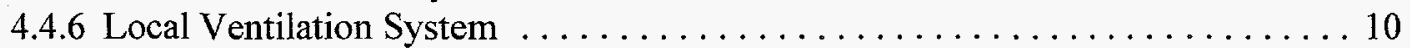

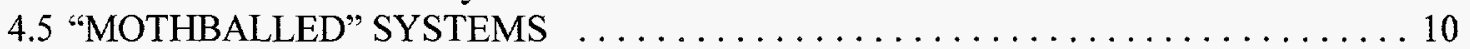

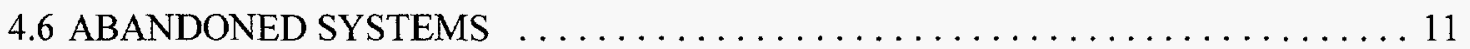

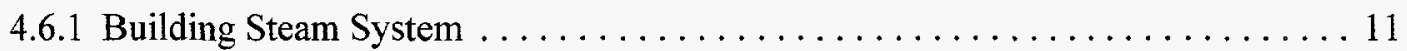

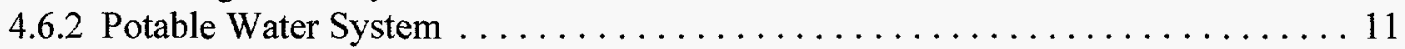

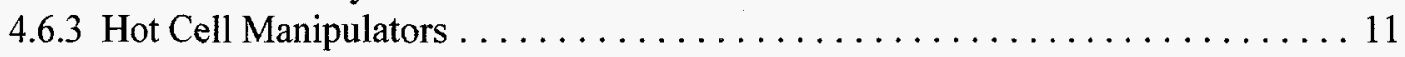

4.6 .4 Natural Gas System . . . . . . . . . . . . . . . . . . . . . . . . . . . 11

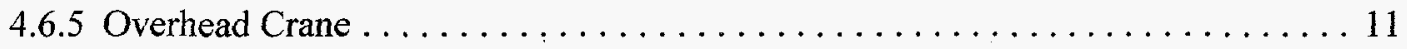

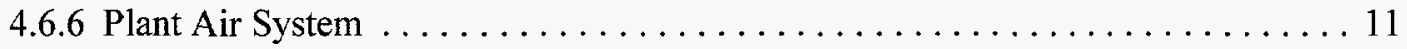

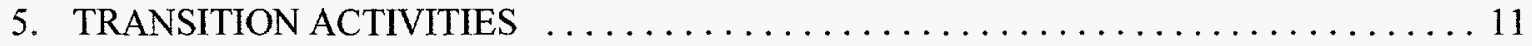

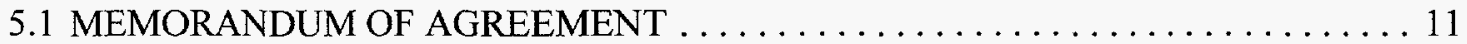

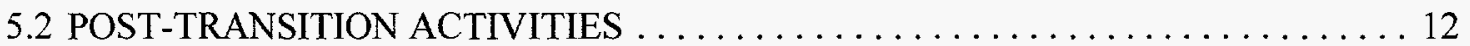

6. POSTDEACTIVATION SURVEILLANCE AND MAINTENANCE $\ldots \ldots \ldots \ldots \ldots \ldots$

7. ABNORMAL ACTIVITIES/CONDITIONS $\ldots \ldots \ldots \ldots \ldots \ldots \ldots \ldots \ldots \ldots \ldots \ldots \ldots$

8. TURNOVER PACKAGE DOCUMENTATION $\ldots \ldots \ldots \ldots \ldots \ldots \ldots \ldots \ldots \ldots \ldots$

8.1 ADMINISTRATIVE TURNOVER PACKAGE $\ldots \ldots \ldots \ldots \ldots \ldots \ldots \ldots \ldots \ldots \ldots \ldots$

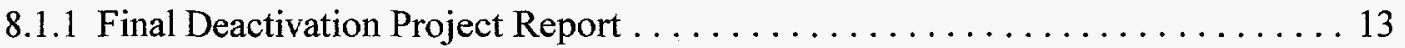

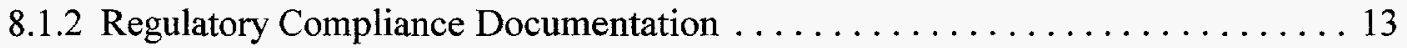

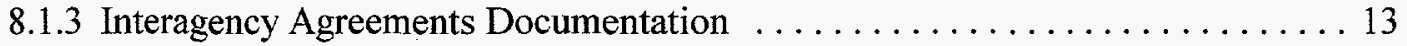

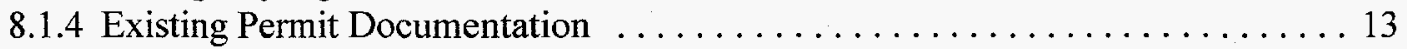

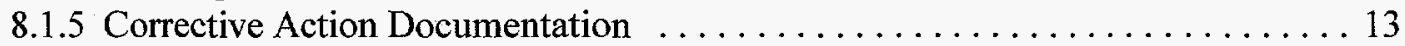

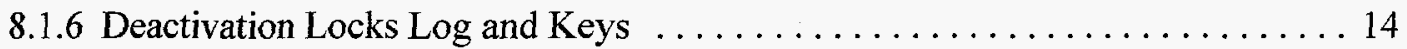

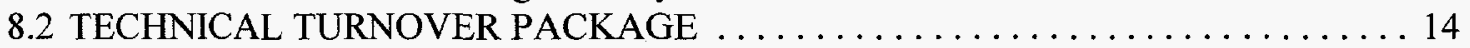

8.2.1 Updated Facility Drawings (Arrangement, PID, Loop, Etc.) . . . . . . . . 14

8.2.2 "As Left" Photos of Spaces and Major Equipment . . . . . . . . . . . 14

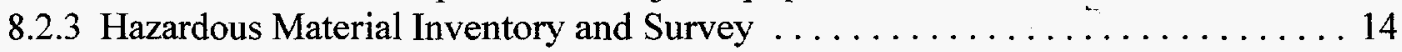

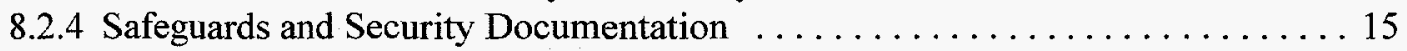

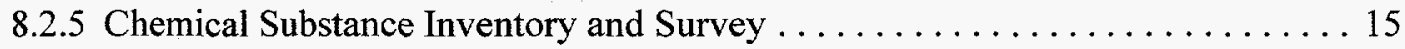

8.2.6 Radioactive Materials Inventory and Survey .................. 15

8.2.7 Facility Soil, Surface Water, and Groundwater Condition Report . . . . . . . 15

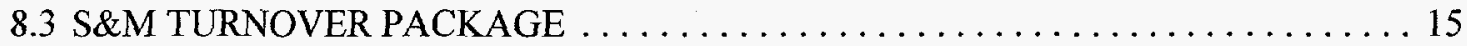

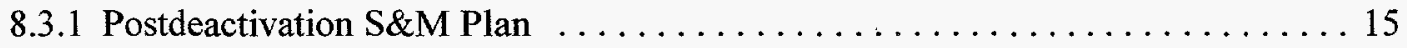

8.3.2 Postdeactivation S\&M Updated Safety Equipment List $\ldots \ldots \ldots \ldots \ldots \ldots \ldots$

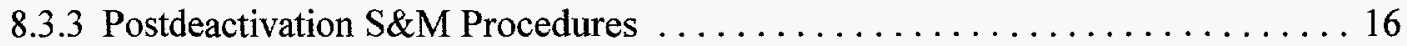

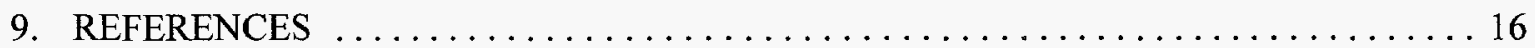

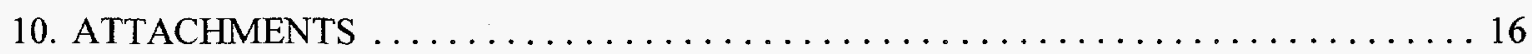


ATTACHMENT 1. BUILDING 3031 FLOOR PLAN

ATTACHMENT 2. BUILDING 3031 PREDEACTIVATION FACILITY PHOTOGRAPHS

ATTACHMENT 3. BUILDING 3031 POSTDEACTIVATION FACILITY PHOTOGRAPHS

ATTACHMENT 4. ADMINISTRATIVE TURNOVER PACKAGE CHECKLIST

ATTACHMENT 5. TECHNICAL TURNOVER PACKAGE CHECKLIST

ATTACHMENT 6. S\&M TURNOVER PACKAGE CHECKLIST

ATTACHMENT 7. BUILDING 3031 DRAWING LIST

ATTACHMENT 8. BUILDING 3031 RADIOLOGICAL SURVEY DATA

vii 



\section{TABLES}

1 Predeactivation radioactive contamination levels $\ldots \ldots \ldots \ldots \ldots \ldots \ldots \ldots \ldots \ldots$

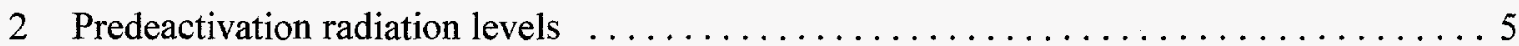

3 Building 3031 predeactivation hazardous materials and waste $\ldots \ldots \ldots \ldots \ldots \ldots \ldots$

4 Postdeactivation radioactive contamination levels $\ldots \ldots \ldots \ldots \ldots \ldots \ldots \ldots \ldots$

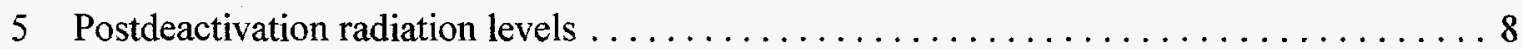

6 Building 3031 postdeactivation hazardous materials and waste $\ldots \ldots \ldots \ldots \ldots \ldots \ldots$

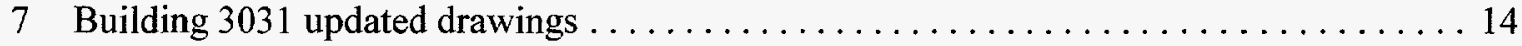

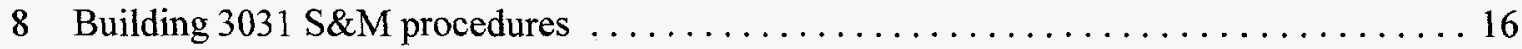





\section{ABBREVIATIONS}

EM-40

EM-60

HEPA

MOA

ORNL

RCRA

S\&M
Department of Energy Office of Environmental Restoration Department of Energy Office of Nuclear Materials and Facility Stabilization high-efficiency particulate air Memorandum of Agreement Oak Ridge National Laboratory Resource Conservation and Recovery Act surveillance and maintenance 



\section{DEFINITIONS}

Deactivation

Decommissioning

Decontamination

End Point

End Point Technical Information

Turnover Package
The process of placing a facility in a safe and stable condition to minimize the long-term cost of a surveillance and maintenance program that is protective of workers, the public, and the environment until decommissioning is completed.

Refers to the ultimate disposition of a facility. Also substitutes for previously used "D\&D."

The removal or reduction of radioactive or hazardous contamination from facilities, equipment, or soils by washing, heating, chemical or electro-chemical action, mechanical cleaning or other techniques to achieve a stated objective or end condition.

A detailed specification for the final deactivation condition of areas and hardware within a facility and related documentation. An individual milestone towards the deactivation and/or the decommissioning of a facility.

A compilation of documents to support end point conclusions.

A compilation of project-related documents to be given to a postdeactivation organization. 



\section{EXECUTIVE SUMMARY}

The purpose of this report is to document the condition of Bldg. 3031 after completion of deactivation activities as outlined by the Department of Energy Office of Nuclear Materials and Facility Stabilization Program (EM-60) guidance documentation. This report outlines the activities conducted to place the facility in a safe and environmentally sound condition for transfer to the Department of Energy Office of Environmental Restoration (EM-40) Program.

This report provides a profile of Bldg. 3031 before and after deactivation activities. Turnover items, such as the Postdeactivation Survellance \& Maintenance Plan, remaining hazardous materials, radiological controls, Safeguards and Security, quality assurance, facility operations, and supporting documentation provided in the Office of Nuclear Materials and Facility Stabilization Program (EM-60) Turnover package, are discussed.

Building 3031 will require access to facilitate required surveillance and maintenance activities to maintain the building safety envelope. Building 3031 was stabilized during deactivation so that when transferred to the EM- 40 program, only a minimal surveillance and maintenance effort would be required to maintain the building safety envelope. Other than the minimal surveillance and maintenance activities, the building will be unoccupied and the exterior doors locked to prevent unauthorized access. The building will be entered only to perform the required surveillance and maintenance.

All materials have been removed from the building and the hot cell, and all utility systems, piping, and alarms have been deactivated. 
note

$y^{2} x^{2}$

3 


\section{INTRODUCTION}

\subsection{PURPOSE}

This report documents the condition of Bldg. 3031 after completion of deactivation activities as outlined by the Department of Energy Office of Nuclear Materials and Facility Stabilization (EM-60) Program guidance documentation. This report outlines the activities conducted to place the facility in a safe and environmentally sound condition for transfer to the Department of Energy Office of Environmental Restoration (EM-40) Program.

This report provides a profile of Bldg. 3031 before and after deactivation activities. Turnover items, such as the Postdeactivation Surveillance \& Maintenance Plan, remaining hazardous materials, radiological controls, Safeguards and Security, quality assurance, facility operations, and supporting documentation provided in the Office of Nuclear Materials and Facility Stabilization (EM-60) Program Turnover package, are discussed.

\subsection{SCOPE}

This report addresses the activities performed during deactivation associated with Bldg. 3031, to place the facility in a safe and environmentally sound condition to await decommissioning, the status of the facility, and the activities required to maintain the facility following deactivation. Attachment 1, "Building 3031 Floor Plan," provides a floor plan of Bldg. 3031 that illustrates the physical boundaries and scope of this Final Deactivation Project Report, the scope of which is limited to Bldg. 3031.

\section{BACKGROUND}

\subsection{FACILITY DESCRIPTION}

Building 3031 is a steel-frame structure covered by corrugated aluminum siding. The single-story facility has a floor area of $825 \mathrm{ft}^{2}$. A manipulator-type hot cell is located on the middle of the west wall. Two laboratory-type hoods occupy the northeast corner of the building with one laboratory-type hood occupying the northwest corner of the building. A laboratory-type workbench occupies the center of the facility and is equipped with a sink. The manipulator cell and laboratory hoods constitute the primary means of containment. All high-level work was conducted in the hot cell. The building operates at a slightly negative pressure relative to the outside atmosphere.

The hot cell has 2-ft barytes concrete walls with 4 in. of lead brick shielding on the operating face of the cell wall and an unshielded top cover. The cell is provided with a mineral-oil-filled lead glass window. A stainless-steel operating pan covers the floor and interior walls up to the level of the viewing window. Small steel doors on each side of the cell are used for the insertion and removal of small equipment and containers. A thick steel double door at the back of the cell provides access for larger items if needed. 
Extended reach Model-8 manipulators are inserted through holes in the top of the cell. The slave sections of the manipulators are covered with urethane manipulator boots sealed to the inside top surfaces of the cells. An additional plastic boot and wiper seals in the manipulator barrels provide a secondary containment for manipulator penetration.

\subsection{FACILITY HISTORY}

Building 3031 was constructed in 1950 as part of the Isotopes Program. The building contains facilities that were utilized for storage, purification, processing, and dispensing of a wide variety of radioisotopes. Primarily these isotopes were processed from irradiated targets from the High-Flux Isotope Reactor, the Oak Ridge Research Reactor, and the 86 in. Cyclotron. The hot cell in Bldg. 3031 was utilized for the final separation of gadolinium $\left({ }^{153} \mathrm{Gd}\right)$.

\section{FACILITY STATUS}

\subsection{PREDEACTIVATION FACILITY STATUS}

Following approximately 40 years of operations and processing, Bldg. 3031 was surplused and many of the process systems were abandoned in place. General housekeeping was not maintained, and the building structural integrity was allowed to lapse.

Attachment 2, "Predeactivation Facility Photographs," contains photographs of the building conditions before deactivation activities.

\subsubsection{Hazards Analysis}

No predeactivation hazards analysis was performed. Because only process activities involving less than $100 \mathrm{Ci}$ were performed in Bldg. 3031, it was determined that the facility did not warrant a hazard analysis or safety analysis.

\subsubsection{Internal Spaces}

The general area contained furniture, cabinets, hazardous waste, radioactive waste, and various miscellaneous items used when the facility was in operation. The lead-based paint is chipping and peeling, providing a means of transferring contamination and endangering personnel and the environment.

Predeactivation radioactive contamination levels and radiation levels for the general area are listed in Tables 1 and 2, respectively. Predeactivation hazardous materials and waste located in the general area are listed in Table 3.

\subsubsection{Building Structure and External Spaces}

The structure and roof of Bldg. 3031 were inspected and found to be in generally good condition, with the exception of water in leakage through various paths. 


\subsubsection{Process, Utility, and Support Systems}

\subsubsection{Electrical power system}

Before deactivation, the electrical power system provided power distribution for the electrical service to Bldg. 3031. Typical electrical loads were lighting, heaters, and exhaust fans. A $480 \mathrm{VAC}$ outlet also existed for use with welders and other equipment requiring this service.

\subsubsection{Fire protection system}

The fire protection system is a dry-pipe fire suppression system for Bldg. 3031 and is available for use. The general area was equipped with sprinkler heads and alarms as required by the local fire code. In addition, fire extinguishers were placed strategically in and around Bldg. 3031. The fire protection system is not believed to be contaminated.

\subsubsection{Building steam system}

The building steam system provided steam for use in heating the general area of Bldg. 3031 . Two heat exchangers are located in Bldg. 3031 to provide space heating for personnel. The building steam system is not believed to be contaminated. However, the majority of the steam piping within Bldg. 3031 is lagged with asbestos insulation materials.

\subsubsection{Potable water system}

Before deactivation, the potable water system provided water to the Bldg. 3031 safety shower, hot water heater, and sink. The potable water system is not believed to be contaminated.

\subsubsection{Hot drain system}

Before deactivation, the hot drain system provided a means of discharging liquid process wastes from the hot cells to the liquid low-level waste system. The hot drain system is a gravity drain system to the WC-10 tank in the low level liquid waste system. The hot drain system was determined to be highly contaminated from the process and cleaning activities performed before deactivation.

\subsubsection{Process drain system}

Before deactivation, the process drain system provided a means of removing liquids from the area floor to the Oak Ridge National Laboratory (ORNL) process waste system and treatment facility. The process drain system is a gravity drain system. The process drain system was determined to be contaminated from the process and cleaning activities performed before deactivation.

\subsubsection{Natural gas system}

The natural gas system to Bldg. 3031 was never used. The system has remained isolated from the building since the time of its installation and is not believed to be contaminated. 


\subsubsection{Overhead crane}

Before deactivation, an overhead crane was used in Bldg. 3031 to provide a means of moving heavy equipment in and around the hot cell. The overhead crane was determined to be contaminated from the process activities performed before deactivation.

\subsubsection{Plant air system}

Before deactivation, the plant air system provided 110 psig air to Bldg. 3031 . The plant air system was regulated and used for process activities and instrumentation throughout the facility. The plant air system is not believed to be contaminated.

\subsubsection{Hot cell manipulators}

Before deactivation, the hot cell manipulators provided a means of remote process operation within the hot cell. The hot cell is equipped with Model 8 manipulators. Before deactivation the hot cell manipulator boots and seals were determined to be in poor condition and a potential method for the spread of contamination from the hot cells.

\subsubsection{Central ventilation system}

Before deactivation, the central ventilation system provided exhaust ventilation services to the hot cell in Bldg. 3031. The central ventilation system for Bldg. 3031 was filtered through high-efficiency particulate air (HEPA) filters before discharge to the 3039 stack. The central ventilation system was determined to be contaminated from the process activities performed before deactivation.

\subsubsection{Local ventilation system}

Before deactivation, the local ventilation system provided exhaust ventilation services to the hoods in Bldg. 3031. The local ventilation system for Bldg. 3031 was filtered through HEPA filters before discharging to the atmosphere. The local ventilation system was determined to be very slightly contaminated from the process activities performed before deactivation.

\subsubsection{Radioactive Material, Contamination, and Waste}

Table 1 lists the radioactive contamination levels identified on radiation surveys conducted before deactivation. 
Table 1. Predeactivation radioactive contamination levels

\begin{tabular}{lll}
\hline Identification & \multicolumn{1}{c}{ Description } & \multicolumn{1}{c}{ Quantity } \\
\hline Hot cell & Alpha smear-transferable contamination & Less than $500 \mathrm{dpm} / 100 \mathrm{~cm}^{2}$ \\
Hot cell & Beta/gamma smear-transferable contamination & 1.0 to $40,000 \mathrm{dpm} / 100 \mathrm{~cm}^{2}$ \\
Hood $\# 1$ & Alpha smear--transferable contamination & Less than $500 \mathrm{dpm} / 100 \mathrm{~cm}^{2}$ \\
Hood $\# 1$ & Beta/gamma smear-transferable contamination & $1988 \mathrm{dpm} / 100 \mathrm{~cm}^{2}$ \\
Hood $\# 2$ & Alpha smear-transferable contamination & Less than $500 \mathrm{dpm} / 100 \mathrm{~cm}^{2}$ \\
Hood $\# 2$ & Beta/gamma smear-transferable contamination & $224 \mathrm{dpm} / 100 \mathrm{~cm}^{2}$ \\
Hood $\# 3$ & Alpha smear-transferable contamination & Less than $500 \mathrm{dpm} / 100 \mathrm{~cm}^{2}$ \\
Hood \#3 & Beta/gamma smear-transferable contamination & No detectable contamination \\
General area & Alpha smear-transferable contamination & Less than $500 \mathrm{dpm} / 100 \mathrm{~cm}^{2}$ \\
General area & Beta/gamma smear-transferable contamination & 231 to $2037 \mathrm{dpm} / 100 \mathrm{~cm}^{2}$ \\
\hline
\end{tabular}

Table 2 lists radiation levels identified on radiation surveys conducted before deactivation.

Table 2. Predeactivation radiation levels

\begin{tabular}{lll}
\hline Identification & \multicolumn{1}{c}{ Description } & \multicolumn{1}{c}{ Quantity } \\
\hline Hot cell & Fixed and transferable radiation levels & $36 \mathrm{mRem} / \mathrm{h}$ \\
Hood $\# 1$ & Fixed and transferable radiation levels & $2 \mathrm{mRem} / \mathrm{h}$ \\
Hood $\# 2$ & Fixed and transferable radiation levels & $20,000 \mathrm{dpm}$ \\
Hood \#3 & Fixed and transferable radiation levels & $20,000 \mathrm{dpm}$ \\
General area & Fixed and transferable radiation levels & up to $38 \mathrm{mRem} / \mathrm{h}$ \\
\hline
\end{tabular}

\subsubsection{Hazardous Materials and Waste}

Table 3 lists the hazardous materials and waste identified during facility walkdowns before deactivation.

Table 3. Building 3031 predeactivation hazardous materials and waste

\begin{tabular}{lll}
\hline \multicolumn{1}{c}{ Identification } & \multicolumn{1}{c}{ Description } & \multicolumn{1}{c}{ Quantity } \\
\hline Lead-based paint & Used as wall covering throughout building. & Indeterminate \\
Asbestos floor tiles & Used as floor covering throughout the building. & $\sim 825 \mathrm{ft}^{2}$ \\
Asbestos lagging & Used as pipe lagging throughout the building & Indeterminate \\
PCBs & Electrical devices and transformers & Indeterminate \\
Lead shielding & Used in hot cell walls and window & Indeterminate \\
Mineral oil & Used in hot cell window & Indeterminate \\
\hline
\end{tabular}

\subsection{POSTDEACTIVATION FACILITY STATUS}

Attachment 3, "Postdeactivation Facility Photographs," contains photographs of the building conditions following deactivation activities. 


\subsubsection{Deactivation End Point Completion}

End point criteria for deactivation activities and end point completion documentation are not applicable for Bldg. 3031. The requirement and guidance for these program elements were not developed before Bldg. 3031 deactivation.

\subsubsection{Hazards Analysis}

A postdeactivation hazards screening was performed. This hazards screening placed the facility in the "other industrial" category.

\subsubsection{Internal Spaces}

The miscellaneous items abandoned when the facility was no longer in use have been removed from the general area. No significant combustibles remain in the general area, and the general area of Bldg. 3031 has been decontaminated to remove transferable contamination from access-required spaces. The lead-based paint is chipping and peeling, providing a means of transferring the lead and endangering personnel and the environment.

Postdeactivation radioactive contamination levels and radiation levels for this area are listed in Tables 4 and 5, respectively. Postdeactivation hazardous materials and waste located in this area are listed in Table 6.

\subsubsection{Building Structure and External Spaces}

The structure and roof of Bldg. 3031 were inspected and found to be in generally good condition, with the exception of some water in leakage through various paths.

\subsubsection{Process, Utility, and Support Systems}

\subsubsection{Electrical power system}

All electrical services, with the exception of lighting, have been disconnected or de-energized at the main breaker box.

\subsubsection{Fire protection system}

The fire protection system is a dry system and remains available for use if there is a fire in the building.

\subsubsection{Building steam system}

The building steam system has been isolated, drained, and abandoned in place.

\subsubsection{Potable water system}

The potable water system has been isolated, drained, and abandoned in place. 


\subsubsection{Hot drain system}

The hot drain system has been abandoned in place. All hot cell drains have been plugged to isolate the hot cells and to prevent the potential spread of contamination. The hot drain system remains highly contaminated from the process and cleaning activities performed before deactivation.

\subsubsection{Process drain system}

The process drain system has been abandoned in place. However, the process drain system remains connected to the ORNL process waste system. The process drain system remains contaminated from the process and cleaning activities performed before deactivation.

\subsubsection{Natural gas system}

The natural gas system has been isolated, vented, and abandoned in place.

\subsubsection{Overhead crane}

The overhead crane has been de-energized and abandoned in place. The overhead crane remains contaminated from the process activities performed before deactivation.

\subsubsection{Plant air system}

The plant air system has been isolated, vented, and abandoned in place.

\subsubsection{Hot cell manipulators}

The hot cell manipulator boots and isolation bags were removed and replaced. New boots were placed on the in-cell portion of the manipulators. The plastic boot and wiper that seals around the manipulator were removed. The manipulator control arms were bagged as an added precaution.

\subsubsection{Central ventilation system}

The central ventilation system remains in operation to provide negative pressure for contamination control for the hot cell. All controls associated with the central ventilation system remain in operation as well. The central ventilation system remains highly contaminated from the process activities performed before deactivation.

\subsubsection{Local ventilation system}

The local ventilation system has been removed from service and shut down. The local ventilation system is slightly contaminated from the process activities performed before deactivation.

\subsubsection{Radioactive Material, Contamination, and Waste}

Table 4 lists the radioactive contamination levels identified on radiation surveys conducted following deactivation. 
Table 4. Postdeactivation radioactive contamination levels

\begin{tabular}{lll}
\hline Identification & \multicolumn{1}{c}{ Description } & \multicolumn{1}{c}{ Quantity } \\
\hline Hot cell & Alpha smear-transferable contamination & Less than $500 \mathrm{dpm} / 100 \mathrm{~cm}^{2}$ \\
Hot cell & Beta/gamma smear-transferable contamination & 1.0 to $100000 \mathrm{dpm} / 100 \mathrm{~cm}^{2}$ \\
Hood \#1 & Alpha smear-transferable contamination & Less than $500 \mathrm{dpm} / 100 \mathrm{~cm}^{2}$ \\
Hood \#1 & Beta/gamma smear-transferable contamination & No detectable contamination \\
Hood \#2 & Alpha smear-transferable contamination & Less than $500 \mathrm{dpm} / 100 \mathrm{~cm}^{2}$ \\
Hood \#2 & Beta/gamma smear-transferable contamination & No detectable contamination \\
Hood \#3 & Alpha smear-transferable contamination & Less than $500 \mathrm{dpm} / 100 \mathrm{~cm}^{2}$ \\
Hood \#3 & Beta/gamma smear-transferable contamination & No detectable contamination \\
General area & Alpha smear-transferable contamination & Less than $500 \mathrm{dpm} / 100 \mathrm{~cm}^{2}$ \\
General area & Beta/gamma smear-transferable contamination & 350 to $1057 \mathrm{dpm} / 100 \mathrm{~cm}^{2}$ \\
\hline
\end{tabular}

Table 5 lists radiation levels identified on radiation surveys conducted before deactivation.

Table 5. Postdeactivation radiation levels

\begin{tabular}{lll}
\hline Identification & \multicolumn{1}{c}{ Description } & \multicolumn{1}{c}{ Quantity } \\
\hline Hot cell & Fixed and transferable radiation levels & $30 \mathrm{mRem} / \mathrm{h}$ \\
Hood $\# 1$ & Fixed and transferable radiation levels & $0.7 \mathrm{mRem} / \mathrm{h}$ \\
Hood $\# 2$ & Fixed and transferable radiation levels & $0.4 \mathrm{mRem} / \mathrm{h}$ \\
Hood \#3 & Fixed and transferable radiation levels & Less than $0.1 \mathrm{mRem} / \mathrm{h}$ \\
General area & Fixed and transferable radiation levels & $0.1 \mathrm{mRem} / \mathrm{h}$ \\
\hline
\end{tabular}

\subsubsection{Hazardous Materials and Waste}

Table 6 lists the hazardous materials and waste identified during facility walkdowns following deactivation.

Table 6. Building 3031 postdeactivation hazardous materials and waste

\begin{tabular}{|c|c|c|}
\hline Identification & Description & Quantity \\
\hline Lead-based paint & Used as wall covering throughout building. & Indeterminate \\
\hline Asbestos floor tiles & Used as floor covering throughout the building. & $\sim 825 \mathrm{ft}^{2}$ \\
\hline Asbestos lagging & Used as pipe lagging throughout the building & Indeterminate \\
\hline PCBs & Electrical devices and transformers & Indeterminate \\
\hline Lead shielding & Used in hot cell walls and window & Indeterminate \\
\hline Mineral oil & Used in hot cell window & Indeterminate \\
\hline
\end{tabular}

\section{BUILDING 3031 DEACTIVATION ACTIVITIES}

The following section addresses the major activities performed during the deactivation of Bldg. 3031. The objectives of the deactivation process were to place the facility in a passively safe 
and environmentally stable configuration that can be efficiently and cost effectively maintained for an indefinite period of time. The major deactivation issues with regard to Bldg. 3031 are discussed in this chapter.

\subsection{INTERNAL SPACES: ACCESS REQUIRED}

\subsubsection{General Areas}

All storage cabinets, desks, file cabinets, and miscellaneous office materials were removed from the building. Some were green-tagged for reuse. The remaining items were disposed of. The asbestos floor tiles were not removed and are not intended to be removed until facility decontamination and decommissioning.

Lead-based paint exists throughout the building as wall covering. The areas that were peeling and flaking have been repaired; the remainder of the paint will remain as is. Paint condition is an inspection item in the surveillance and maintenance plan for Bldg. 3031.

\subsection{INTERNAL SPACES: NO ACCESS REQUIRED}

\subsubsection{Hot Cell}

The following deactivation activities were performed in the hot cell:

- The hot cell manipulator boots and isolation bags were removed and replaced. New boots were placed on the in-cell portion of the manipulators. The plastic boot and wiper that seals around the manipulator were removed.

- The hot cell was wiped down to reduce airborne contamination.

- All hot cell service lines were identified, labeled, and plugged.

- All in-cell filters were removed.

- All hot cell drains were plugged.

- Access to the hot cell was secured.

\subsection{EXTERNAL SPACES}

\subsubsection{Building 3031 Structure}

The exterior of Bldg. 3031 was inspected and found to be in generally good structural condition. The building exterior has been sealed to eliminate air and water in leakage and to provide an effective containment for the building. 


\subsubsection{Building 3031 Roof}

The roof of Bldg. 3031 was repaired/inspected and found to be in generally good structural condition.

\subsection{OPERATIONAL SYSTEMS}

\subsubsection{Electrical Power System}

All electrical services that were not essential to the basic surveillance and maintenance operations were disconnected at the main breaker box.

\subsubsection{Fire Protection System}

The fire protection is a dry pipe delivery system available for use if there is a fire in the building.

\subsubsection{Hot Drain System}

The hot drains from the hot cells were plugged with Plexiglas plugs to isolate the hot cells and prevent the spread of contamination. No decontamination of the hot drain system has been performed.

\subsubsection{Process Drain System}

The process floor drains remain in operation to direct any roof in leakage to the ORNL process waste system and prevent any uncontrolled contamination from leaving the building. No decontamination of the process drain system has been performed.

\subsubsection{Central Ventilation System}

The central ventilation system remains in operation to provide negative pressure for contamination control for the hot cell. All controls associated with the central ventilation system remain in operation as well. No decontamination of the central ventilation system has been performed.

\subsubsection{Local Ventilation System}

The local ventilation system has been removed from service and shut down in place. No decontamination of the local ventilation system has been performed.

\section{5 "MOTHBALLED" SYSTEMS}

No "mothballed" systems are associated with Bldg. 3031. 


\subsection{ABANDONED SYSTEMS}

\subsubsection{Building Steam System}

The building steam system supply was drained and valved off.

\subsubsection{Potable Water System}

Potable water has been isolated from Bldg. 3031 by capping the incoming line.

\subsubsection{Hot Cell Manipulators}

The hot cell manipulator boots and isolation bags were removed and replaced. New boots were placed on the in-cell portion of the manipulators. The plastic boot and wiper that seals around the manipulator were removed. Decontamination was performed, as required, during manipulator boot replacement.

\subsubsection{Natural Gas System}

Natural gas was vented and valved off.

\subsubsection{Overhead Crane}

The overhead crane was de-energized and abandoned in place. Minor decontamination was performed on the overhead crane to minimize the potential spread of contamination.

\subsubsection{Plant Air System}

The plant air system has been depressurized and valved off.

\section{TRANSITION ACTIVITIES}

Building 3031 will be officially transferred from the EM- 60 program to the EM-40 program by a Memorandum of Agreement (MOA). The building will be accepted "as is" by EM-40 at the time of transfer.

\subsection{MEMORANDUM OF AGREEMENT}

The MOA documents the requirements agreed upon between Office of Environmental Restoration (EM-40) and Office of Facility Transition and Management. The signed MOA indicates acceptance by EM-40 that the criteria outlined in the MOA have been completed satisfactorily, with the exception of post-transition punchlist items, and that the level of deactivation of the facility is acceptable for transition to the EM-40 program. Post-transition punchlist items will be finished after deactivation is complete. The details of how the punchlist items will be completed and documented will be addressed in the MOA. 


\subsection{POST-TRANSITION ACTIVITIES}

No post-transition punchlist items have been identified for Bldg. 3031. All deactivation activities have been completed before transfer to EM-40.

\section{POSTDEACTIVATION SURVEILLANCE AND MAINTENANCE}

The "Postdeactivation S\&M Plan for Building 3031" covers surveillance and maintenance (S\&M) activities associated with the interior spaces, operational and mothballed systems, and external areas related to Bldg. 3031.

The specific objectives of the S\&M program for Bldg. 3031 are as follows:

1. ensure adequate containment of contamination;

2. provide physical safety and security control;

3. maintain the facility in a manner that will minimize potential hazards to the public; and

4. provide a mechanism for the identification and compliance with applicable environmental, safety, and health requirements.

The "Postdeactivation S\&M Plan for Building 3031" details the specific S\&M items to be performed and estimates the annual cost of performance. The S\&M cost estimates are based on previous operational costs associated with similar S\&M activities at ORNL.

The S\&M activities associated with Bldg. 3031 include the following types of activities:

- walkdowns and inspections for structural integrity, safety, radioactive contamination, and hazardous material conditions;

- general housekeeping of the interior and exterior of the building as needed; and

- maintenance activities required to maintain the security and safety envelope of the facility.

\section{ABNORMAL ACTIVITIES/CONDITIONS}

No abnormal activities/conditions have been identified for Bldg. 3031. 


\section{TURNOVER PACKAGE DOCUMENTATION}

\subsection{ADMINISTRATIVE TURNOVER PACKAGE}

Administrative turnover consists of a collection of administrative documents. This includes procedures, agreements, and other documents not directly related to the physical facility. The level of detail depends on the conditions, requirements, and agreements specific to the facility.

Attachment 4, "Administrative Turnover Package Checklist," reflects the documents required for this facility with respect to administrative turnover. The following sections detail the contents of the applicable sections required for Bldg. 3031.

\subsubsection{Final Deactivation Project Report}

A management summary of the facility deactivation completion, general status, and conditions, demonstrating conformance with the U.S. Department of Energy's specification of the overall end point. It identifies management actions needed that are not routine and describes unresolved issues.

\subsubsection{Regulatory Compliance Documentation}

Regulatory compliance documentation discusses the status/compliance of all regulatory commitments, including the status of compliance with applicable regulations promulgated pursuant to statutes - such as Occupational Safety and Health Administration; Resource Conservation and Recovery Act (RCRA); Comprehensive Environmental Response, Compensation, and Liability Act; and National Environmental Policy Act - and the remediation process in the National Contingency Plan.

\subsubsection{Interagency Agreements Documentation}

Interagency Agreements documentation covers Interagency Agreements that identify the terms and milestones of agreements pending and entered into by the U.S. Department of Energy with federal, state, and local agencies and the status of compliance. This includes settlement agreements, administrative or consent orders, and compliance plans to settle outstanding notices of violation.

\subsubsection{Existing Permit Documentation}

Existing permit documentation details the status of existing permits, including National Pollutant Discharge Elimination System, air permits, RCRA, and others associated with the facility.

\subsubsection{Corrective Action Documentation}

Corrective action documentation describes the status of corrective actions completed and outstanding from previous audits, inspections, and other similar activities (e.g., Tiger Team, Technical Safety Appraisal, Defense Nuclear Facilities Safety Board, regulatory agencies, self assessments, business systems review), including identification of those items that need to be reevaluated and reviewed with respect to the facility's surplus condition. 


\subsubsection{Deactivation Locks Log and Keys}

The deactivation locks log lists all deactivation locks and keys for facility access, isolation of electrical components, chaining of valves, and other situations where physical access is to be controlled that will be turned over to EM-40 at the time of transfer.

\subsection{TECHNICAL TURNOVER PACKAGE}

Technical turnover consists of a collection of technical documents that describe the facility, its equipment, and the conditions at the completion of all deactivation activities. The level of detail depends on the conditions, requirements, and agreements specific to the facility. Attachment 5 , "Technical Turnover Package Checklist," reflects the documents required for this facility with respect to technical turnover. The following sections detail the contents of the applicable sections required for Bldg. 3031.

\subsubsection{Updated Facility Drawings (Arrangement, PID, Loop, Etc.)}

Facility, room, and cell arrangement drawings - to the extent they exist. However, except in unique circumstances, as-built drawings of the deactivated conditions within the facility are not provided.

Provides current status (including drawings) of the deactivation/safe shutdown (if applicable). The documentation addresses systems, such as the water, sewer, air, electric, gas, process (mechanical and chemical), and fire protection systems.

See Attachment 7, "Building 3031 Drawing List," for a list of drawings.

Table 7. Building 3031 updated drawings

\begin{tabular}{lcl}
\hline \multicolumn{1}{c}{ Number } & Rev. & \multicolumn{1}{c}{ Title } \\
\hline D-37907 & A & Manipulator cell-service piping and ventilation-sections \& details \\
D-6615 & A & Isotope process area-Process Bldg. "C"-heating and exhaust system \\
E-30097 & & Storage vault-mechanical and electrical-plans and details-sheet 3 \\
H203369EG-002-D & 001 & A/C elec. roof plan A/C units isotope area \\
D-51926 & A & Enclosure Bldgs. 3030 and 3031-ventilation \\
D-51926 & & Piping, heating and ventilation \\
\hline
\end{tabular}

\subsection{2 "As Left" Photos of Spaces and Major Equipment}

"As left" photos of spaces and major equipment include descriptions and photos of spaces for which access is not anticipated during S\&M.

\subsubsection{Hazardous Material Inventory and Survey}

The hazardous material inventory and survey describes the location of fixed hazardous materials, wastes, and contamination with characterization information. 


\subsubsection{Safeguards and Security Documentation}

Safeguards and security documentation describes the inventory and safeguards and security provisions for nuclear or other material remaining in the facility for which there is a requirement for accountability or protection from diversion.

\subsubsection{Chemical Substance Inventory and Survey}

The chemical substance inventory and survey is an inventory of chemical and hazardous substances remaining, if any, and their characterization information.

\subsubsection{Radioactive Materials Inventory and Survey}

The radioactive materials inventory and survey is an inventory of radioactive and fissile material remaining as contamination with characterization information and includes the final radiological/hazardous materials survey records, final configuration and surveillance and maintenance requirements, available drawings, specifications, procedures, manuals, and unplanned occurrences records applicable to the facility. Data from the radiological survey are listed in Attachment 8, "Building 3031 Radiological Survey Data."

\subsubsection{Facility Soil, Surface Water, and Groundwater Condition Report}

For soil, surface water, and groundwater conditions at the facility, this report provides all available data, describes those conditions and the nature and extent of contamination therein, and identifies any known assessment requirements.

\subsection{S\&M TURNOVER PACKAGE}

S\&M turnover consists of a collection of documents required to support Postdeactivation S\&M activities. The level of detail depends on the S\&M specific to the facility. Attachment 6, "S\&M Turnover Package Checklist," reflects the documents required for this facility with respect to S\&M turnover. The following sections detail the contents of the applicable sections required for Bldg. 3031.

\subsubsection{Postdeactivation S\&M Plan}

This document describes the S\&M plan for the facility after deactivation is complete, up to the initiation of decommissioning. The $S \& M$ activities will be integrated into the decommissioning work and phased out as decommissioning is completed.

\subsubsection{Postdeactivation S\&M Updated Safety Equipment List}

This document describes the safety equipment that will remain in the facility during the postdeactivation S\&M period. 


\title{
8.3.3 Postdeactivation S\&M Procedures
}

Table 8 contains a list of procedures required during the postdeactivation S\&M period. These procedures outline the maintenance activities and special surveillances required to ensure that the facility conditions and safety envelope remain consistent until decommissioning can take place.

Table 8. Building 3031 S\&M procedures

\begin{tabular}{ll}
\hline \multicolumn{1}{c}{ Number } & \multicolumn{1}{c}{ Procedure title } \\
\hline IP-1418 & Manipulator Removal, Repair, and Replacement \\
IP-1313, Rev. 2 & Local and Central Ventilation System HEPA Filter Replacement \\
\hline
\end{tabular}

\section{REFERENCES}

\author{
Document \\ $\underline{\text { Document Title }}$ \\ Number \\ Draft \\ Facility Deactivation End Points Handbook; Volume 1: Method and \\ Examples. \\ Draft Facility Deactivation End Points Handbook; Volume 2: Deactivation \\ Practices. \\ DOE/EM-0246 Decommissioning Resource Manual. August 1995 \\ ORNL/ER-249/R2 Martin Marietta Environmental Restoration Program; Work Plan for \\ the Isotopes Facilities Deactivation Project at Oak Ridge National \\ Laboratory, August 1995 \\ Oak Ridge National Laboratory; Local Emergency Manual, Isotope \\ Area, Revision 94-1, January 1994
}

\section{ATTACHMENTS}

1. Building 3031 Floor Plan

2. Building 3031 Predeactivation Facility Photographs

3. Building 3031 Postdeactivation Facility Photographs

4. Administrative Turnover Package Checklist

5. Technical Turnover Package Checklist

6. S\&M Turnover Package Checklist

7. Building 3031 Drawing List

8. Building 3031 Radiological Survey Data 
ATTACHMENT 1

BUILDING 3031

FLOOR PLAN 

ORNL DWG 97C-251

\section{Building 3031}

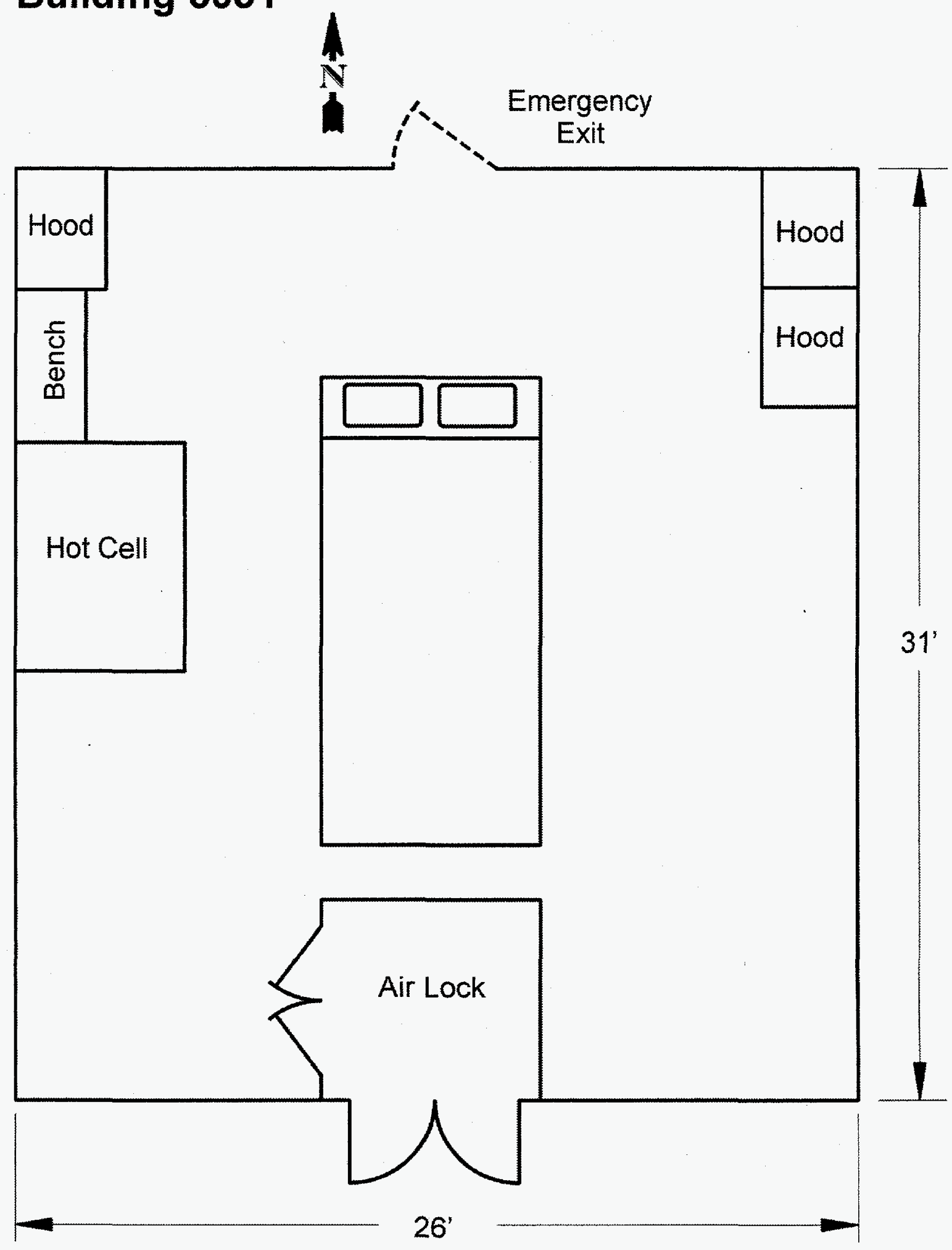





\section{ATTACHMENT 2 \\ BUILDING 3031 \\ PREDEACTIVATION FACILITY PHOTOGRAPHS}





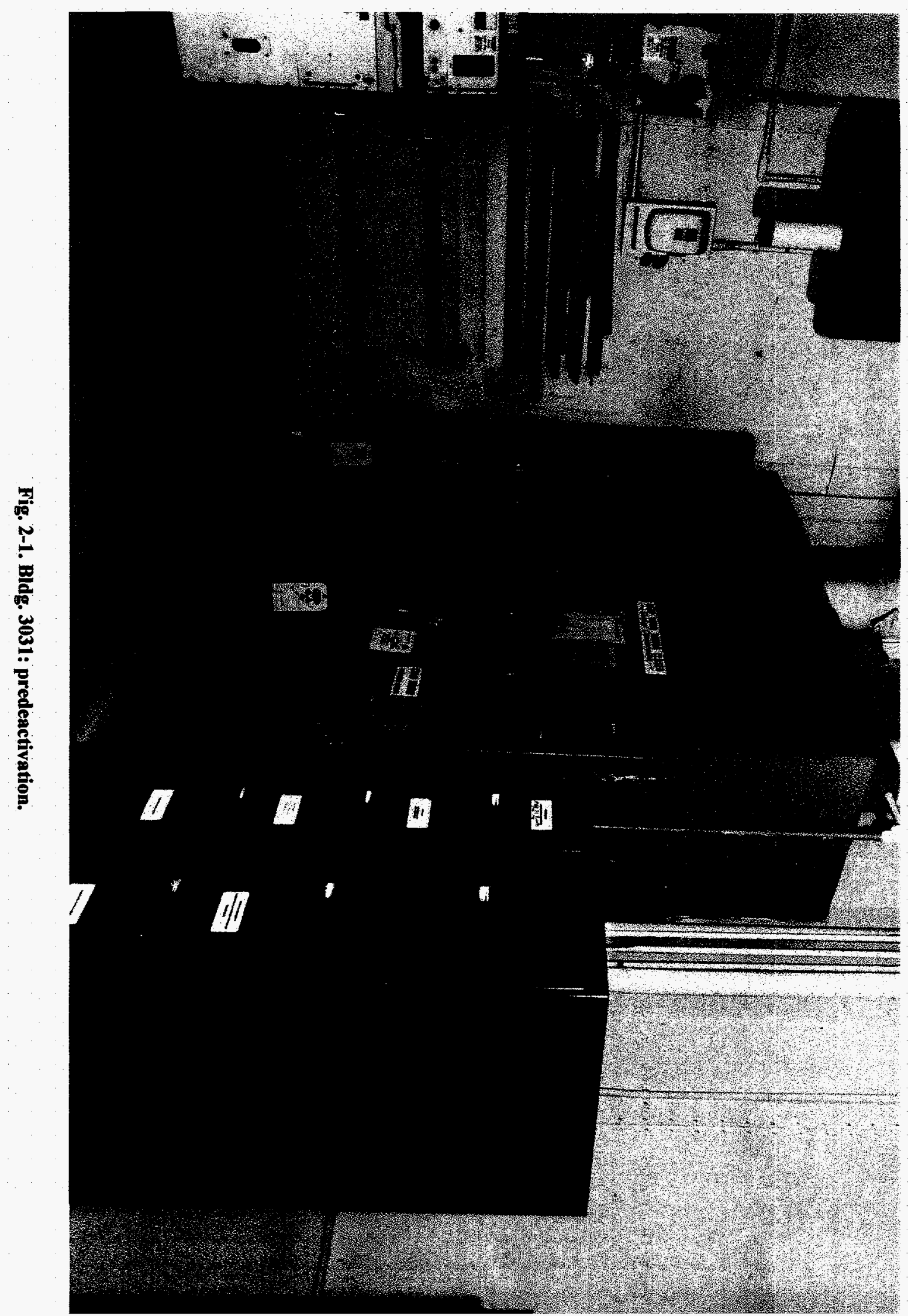




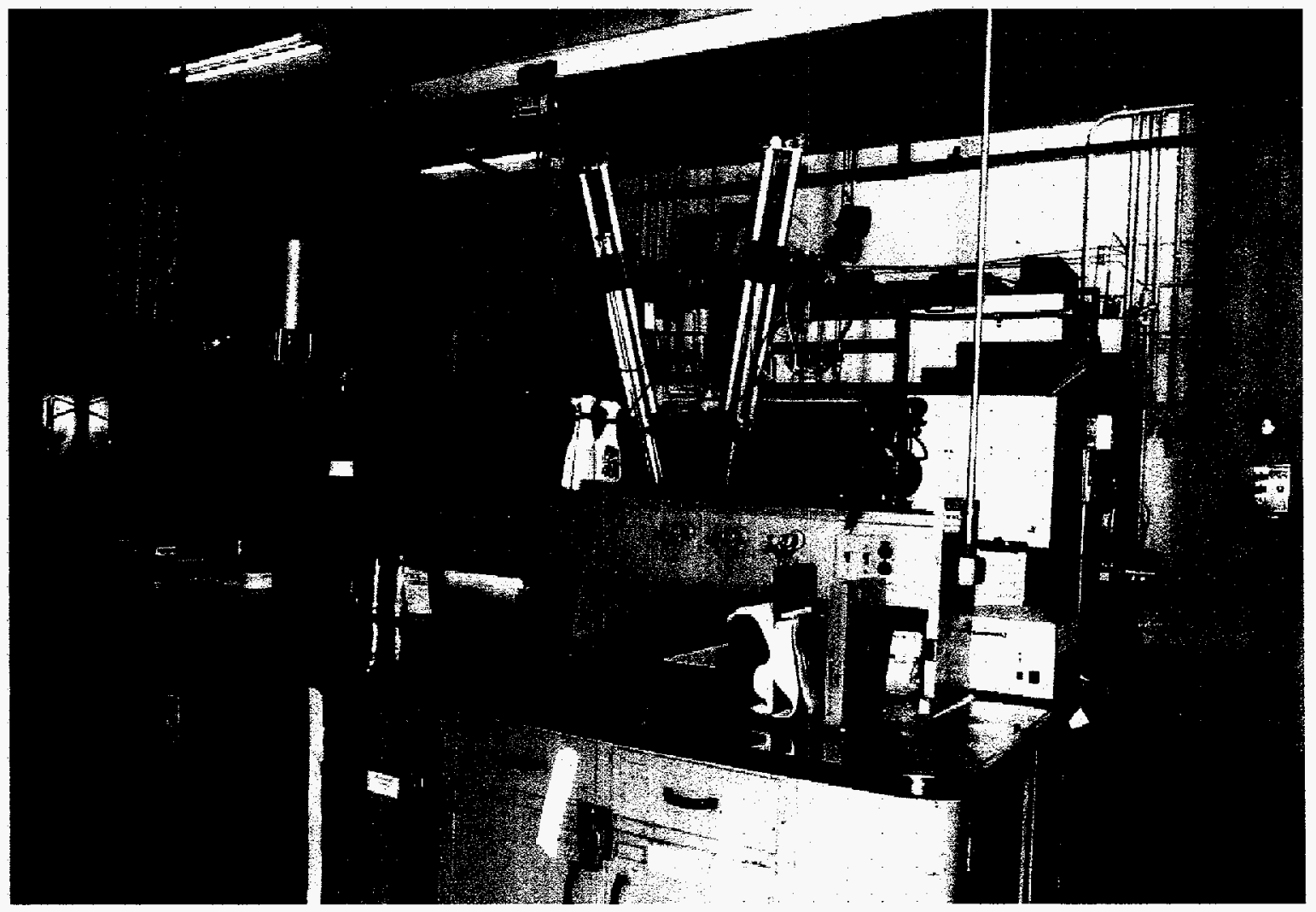

Fig. 2-2. Bldg. 3031: predeactivation. 
ATTACHMENT 3

BUILDING 3031

POSTDEACTIVATION FACILITY PHOTOGRAPHS 


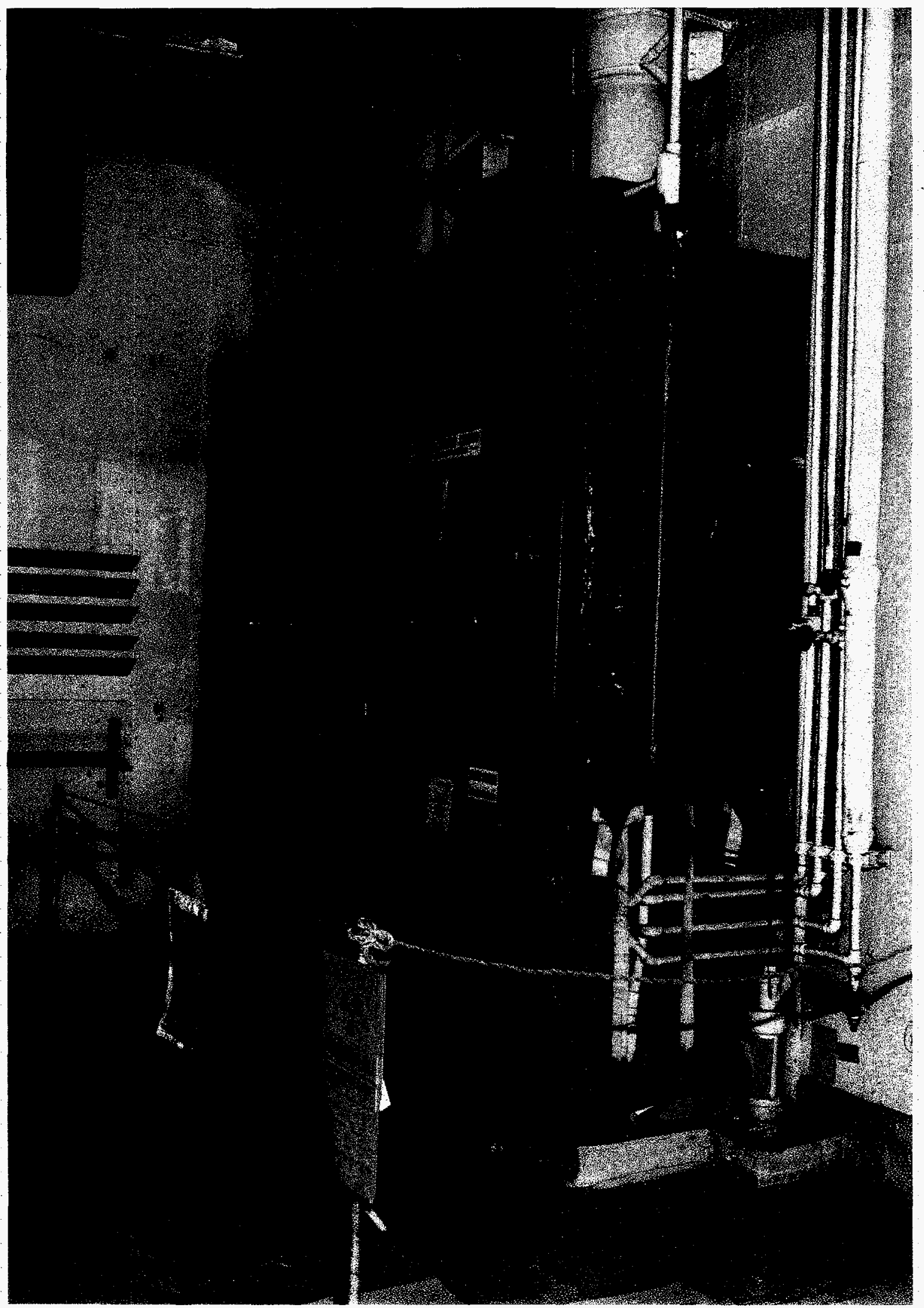

Fig. 3-1. Bldg. 3031: postdeactivation. 


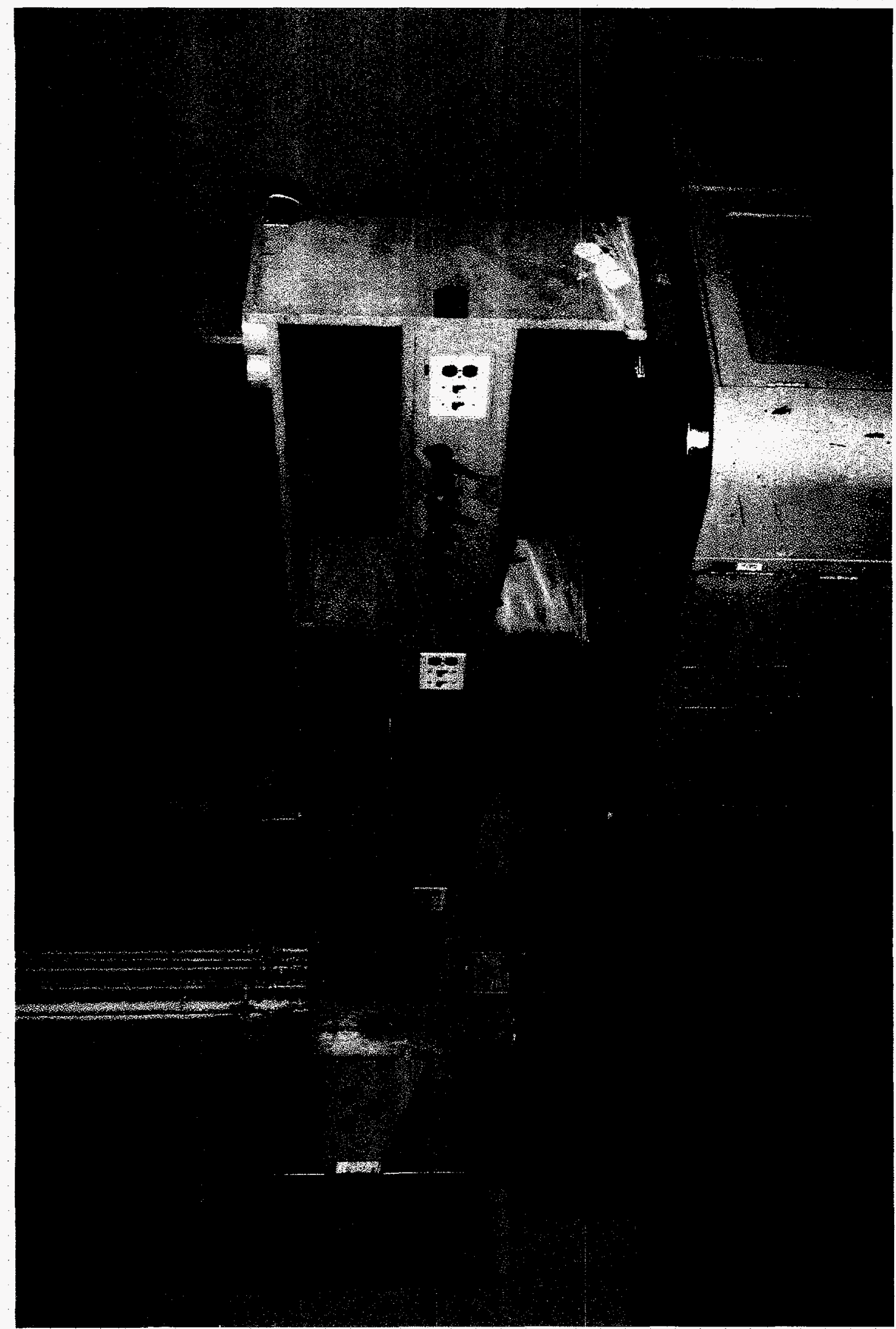

हैं 


\section{ATTACHMENT 4}

ADMINISTRATIVE TURNOVER

PACKAGE CHECKLIST 

Administrative turnover package checklist

\begin{tabular}{clc}
\hline $\begin{array}{c}\text { Item } \\
\text { number }\end{array}$ & \multicolumn{1}{c}{ Document } & Applicable? \\
\hline 1 & Final Deactivation Project Report & Yes \\
2 & Emergency Response Plan & No \\
3 & Safety Documentation (Category III or greater) & No \\
4 & Regulatory Compliance Documentation & No \\
5 & Interagency Agreements Documentation & No \\
6 & Existing Permit Documentation & No \\
7 & Corrective Action Documentation & No \\
8 & Postdeactivation Punchlist & No \\
9 & Deactivation Locks and Keys & Yes \\
\hline
\end{tabular}



ATTACHMENT 5

TECHNICAL TURNOVER

PACKAGE CHECKLIST 

Technical turnover package checklist

\begin{tabular}{clc}
$\begin{array}{c}\text { Item } \\
\text { number }\end{array}$ & \multicolumn{1}{c}{ Document } & Applicable \\
$?$
\end{tabular}



ATTACHMENT 6

S\&M TURNOVER

PACKAGE CHECKLIST 

S\&M turnover package checklist

\begin{tabular}{clc}
\hline $\begin{array}{c}\text { Item } \\
\text { number }\end{array}$ & \multicolumn{1}{c}{ Document } & Applicable? \\
\hline 1 & Postdeactivation Surveillance and Maintenance Plan & Yes \\
2 & $\begin{array}{l}\text { Postdeactivation Surveillance and Maintenance Updated } \\
\text { Effluent Monitoring Plan }\end{array}$ & No \\
3 & $\begin{array}{l}\text { Postdeactivation Surveillance and Maintenance Updated } \\
\text { Safety Equipment List }\end{array}$ & Yes \\
4 & $\begin{array}{l}\text { Postdeactivation Surveillance and Maintenance Procedures } \\
5\end{array}$ & $\begin{array}{l}\text { Postdeactivation Surveillance and Maintenance } \\
\text { Recommendations }\end{array}$ \\
6 & Mothballed Systems Lay-up and Restart Documentation & No \\
\end{tabular}



ATTACHMENT 7

BUILDING 3031

DRAWING LIST 

Building 3031 drawing list

\begin{tabular}{|c|c|c|}
\hline Document number & Revision & Title \\
\hline A-36615 & & Plan Manip. Cell \\
\hline A-36616 & & Sect. B-B Manip. Cell \\
\hline C-28458 & & Interim Low Level Analytical Facility - Floor Plan \\
\hline C-28459 & & Interim Low Level Analytical Facility - Section "A-A" \\
\hline C-28460 & & Interim Low Level Analytical Facility - Section "B-B" \\
\hline C3E-020366-A001 & & $\begin{array}{l}\text { Reroof Bldgs. 3030, 3031, } 3118 \text { - Site Access Plan and Drawing } \\
\text { Index }\end{array}$ \\
\hline D-32377 & & Interim Low Level Analytical Lab. - Floor Plan - Section B-B \& C-C \\
\hline D-32378 & & $\begin{array}{l}\text { Interim Low Level Analytical Lab. - Entrance Plans \& Details - Sec. - } \\
\text { A-A }\end{array}$ \\
\hline D-36280 & & Manip. Cells Plans, Sects. \& Elevs. \\
\hline D-36320 & & Manip. Cell for Bldg. 3031 Plans, Elev. \\
\hline D-37906 & & Manip. Cell Serv. Piping Plan \& Elev. \\
\hline D-37907 & A & Manipulator Cell - Service Piping \& Ventilation - Sections \& Details \\
\hline D-37908 & & Manip. Cell Det. Sht. \\
\hline D-37921 & & Manip. Cell Serv. Piping - Plan \\
\hline D-38003 & 002 & Locations Foundations Plans Dets. \\
\hline D-38004 & 002 & Horizontal Vertical Sections \\
\hline D-38005 & 002 & Roof Plan Elevation Dets. \\
\hline D-38006 & 001 & Loading Doors Steel Panel Dets. \\
\hline D-38007 & 001 & Port Doors Steel Panel Doors \\
\hline D-38008 & 002 & Lead Glass Window Steel Panel Dets. \\
\hline D-38009 & 001 & Bar Anchor For Stainless Steel Liners \\
\hline D-38219 & & Concrete Approach Pad Plans Sect. Dets. \\
\hline D-38428 & & Manip. Cell Elec. Plans \& Elev. \\
\hline D-43024 & & Resurfacing at Low Level Facility \\
\hline D-46696 & 002 & Det. of New Radioactive Waste Drains \\
\hline D-56569 & & Foundation Plan Sect. \& Dets. \\
\hline D-56570 & & Floor Plan and Steel Framing Details Bldgs. 3030 and 3031 \\
\hline D-56571 & & Wall Sects. \\
\hline D-56572 & & Radioactive Waste Drains \& Curbs \\
\hline D-6613 & & Bldg. C-D-E Equip. Layout \\
\hline D-6615 & A & Isotope Process Area - Process Bldg. "C" - Heating \& Exhaust System \\
\hline
\end{tabular}


$7-4$

Building 3031 drawing list (continued)

\begin{tabular}{lcl}
\hline Document number & Revision & \multicolumn{1}{c}{ Title } \\
\hline E-30097 & & Storage Vault - Mechanical \& Electrical - Plans \& Details - Sheet 3 \\
H203369EG-002-D & 001 & AVC Elec. Roof Plan A/C Units Isotope Area \\
S3D-20369-B006 & & 500 Monorail Plan \& Sects. \\
S3E-020366-B012 & Reroof Bldgs. 3030, 3031, 3118 - Roof Plan, Sections \& Details \\
S3E-020366-B013 & & Reroof Bldgs. 3030, 3031, 3118 - Sections \& Details \\
D-51926 & A & Enclosure Bldgs. 3030 and 3031 - Ventilation \\
D-51926 & & Piping, Htg. \& Vent. \\
\hline
\end{tabular}


ATTACHMENT 8
BLDG. 3031
RADIOLOGICAL SURVEY DATA 

ORNL Radiological Survey Data

Survey Number: 3038-940163

3038 Field Office

Date: $11 / 3 / 94$

Tima: 10:20

Surveyor Badge Number: $\quad 32721$

Routine Survey

AWP Number: 102156

Bullding: 3031

Specific Locetion: Three hoods

Description:

Final contamination survoy of the three hoods after deconning.

Instruments Used and Callbration Due Date:

CTB-047 2/23/95

Ceneral Deseription of Padiological Conditions:

The maximum smear in hood 1 was $2163 \mathrm{dpm} / 100 \mathrm{~cm} 2$. Max smear in hood 2 was 11,389 dpm/100cm2. This was the only smear that wes over $5,000 \mathrm{dpm}$. Mex smear in hood 3 was $574 \mathrm{dpm} / 100 \mathrm{~cm} 2$. For more details, refer to amear results.

Division or Group Needing the Survey: CT

Pereon-hours spent op the survey:

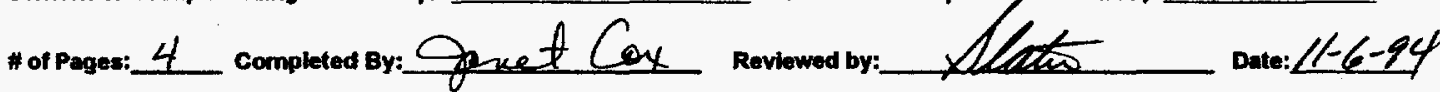

\begin{tabular}{|c|c|c|c|c|c|c|c|c|c|c|c|}
\hline \multicolumn{12}{|c|}{ Smear Results (dpm/100 $\mathrm{cm}^{2}$ unless noted) } \\
\hline \begin{tabular}{c|c|c|} 
Sinear \\
Number
\end{tabular} & $\mathbf{\alpha}$ & $\boldsymbol{\beta}$ & Loeation & $\begin{array}{l}\text { Smear } \\
\text { Number } \\
\end{array}$ & $\alpha$ & $\boldsymbol{\beta}$ & Locention & $\begin{array}{l}\text { Smater } \\
\text { Number }\end{array}$ & $\boldsymbol{\alpha}$ & $\beta$ & Location \\
\hline & $N C$ & $<200$ & See mas & 2 & $\mathrm{NC}$ & $<200$ & See map & 3 & NC & 350 & Se0 $\operatorname{map}$ \\
\hline 4 & NC & 406 & sen mones & 5 & NC & $<200$ & sed mas & 6 & NC & 413 & $\operatorname{sen} \operatorname{sen}$ \\
\hline 7 & NC & $<200$ & See map & 8 & NC & $<200$ & $500 \mathrm{sen}$ & 8 & $\mathrm{NC}$ & $<200$ & 500.00 \\
\hline 10 & NC & 497 & seo map & 11 & NC & 217 & See map & 12 & NC & 595 & $\operatorname{sen} \operatorname{mes}$ \\
\hline 13 & NC & 224 & Ses map & 14 & $\mathrm{NC}$ & $<200$ & $\operatorname{sen} \theta$ & 15 & NC & 350 & ${ }^{\operatorname{sen} \operatorname{nin}_{0}}$ \\
\hline 16 & $\mathrm{NC}$ & 2163 & See map & 17 & NC & 1484 & seensop & 18 & NC & 497 & $800 \mathrm{mos}$ \\
\hline 19 & NC & 357 & $5 e 0$ mate & 20 & NC) & 4263 & sen map & 21 & NC & 301 & seom mep \\
\hline 22 & $\mathrm{NC}$ & 336 & Sen mase & 23 & NC & $<200$ & See map & 24 & NC & $<200$ & Sor map \\
\hline 26 & $\mathrm{NC}$ & 462 & sen map & 26 & NC & $<200$ & Sen map & 27 & $\mathrm{NC}$ & 1344 & Sol $\operatorname{map}$ \\
\hline 28 & $\mathrm{NC}$ & 2247 & $\operatorname{sen} m \infty$ & 29 & NC & 11,389 & som map & 30 & $\mathrm{NC}$ & 4144 & $\sin m$ \\
\hline 31 & NC & 476 & Sen meses & 32 & NC & 539 & sos mas & 33 & NC & 1100 & $\operatorname{sen} m a p$ \\
\hline 34 & NC & 1722 & Sed mas & 35 & NC & 407 & sea mas & 36 & NC & 371 & sen map \\
\hline 37 & $\mathrm{NC}$ & $<200$ & seo max & 38 & $N C$ & $<200$ & Seo nep & 39 & NC & $<200$ & seo mas \\
\hline 40 & NC & $<200$ & $\operatorname{sen} m$ & 41 & NC & $<200$ & 300000 & 42 & NC & $<200$ & $800 \min$ \\
\hline 43 & NC & 231 & Soo map & 44 & $\mathrm{NC}$ & $<200$ & $\operatorname{sen} m$ & 46 & NC & $<200$ & $\sin \min$ \\
\hline 48 & $N C$ & 497 & 8000 & 47 & NC & $<200$ & $\operatorname{sen} m$ & 48 & NC & $<200$ & $\sin m a p$ \\
\hline 49 & $\mathrm{NC}$ & 231 & Sece maxp & 60 & NC & 574 & Set mep & 51 & NC| & 343 & $\sin \operatorname{man}$ \\
\hline
\end{tabular}


ORNL Radiological Survey Data Survey Number: $3038-94-0163 \quad 3038$ Field Office Date: $11 / 3$ la4 Time: 1020

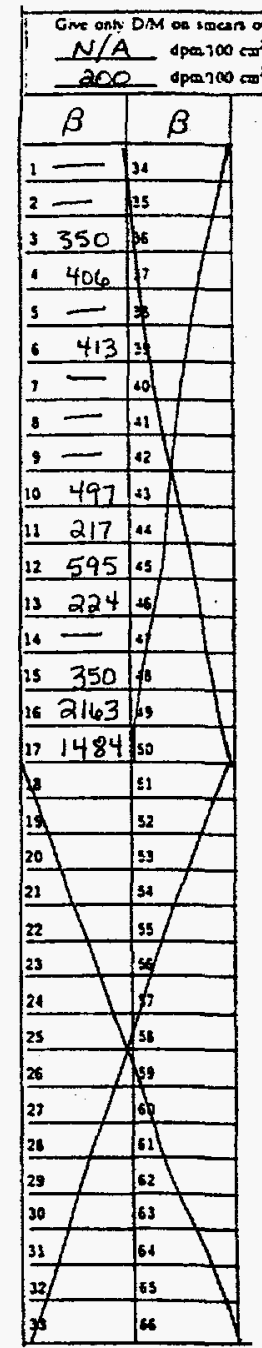

3031
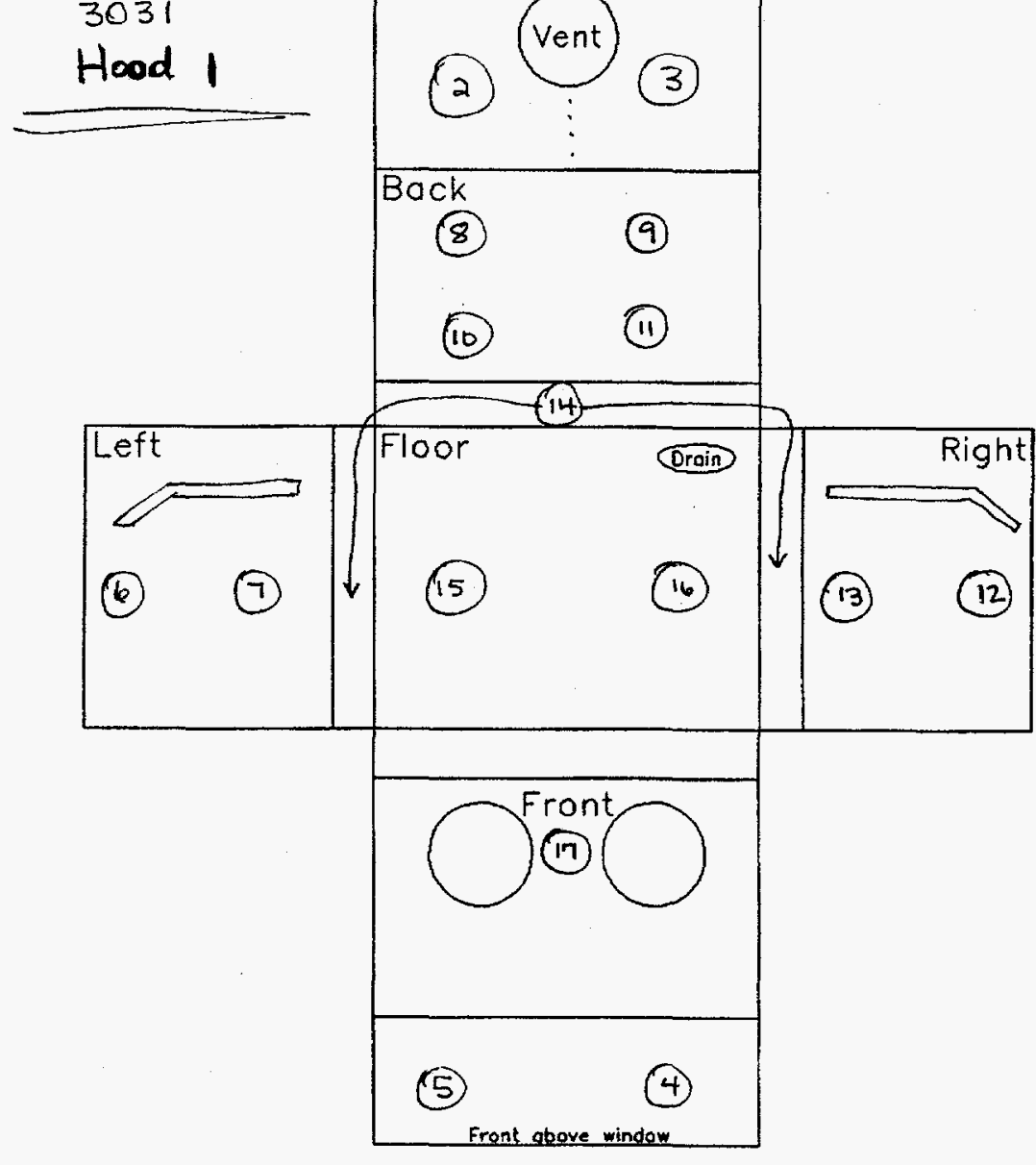

\begin{tabular}{|c|c|c|c|}
\hline (3) & - Smear Location & \multicolumn{2}{|c|}{ Boundery Designations } \\
\hline $9-3$ & - Large Area Smeat & RA-Radiation Area & BA - Radiological Buffer Area \\
\hline 纽 & - Contact Dose Rate & HR - High Radiation Area & CA - Contamination Area \\
\hline $\bar{*}$ & - 30 em Dose Rale & UR - Very High Radlation Are: & HC - High Contamination Area \\
\hline 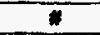 & - Genger A Aren Dosa Rate & AR - Airborne Radloactivity Aren & FC - Fixed Contamination Ares \\
\hline SOP & - Step-off Pad & RM - Radionctive Materials Area & SC-Soll Contamination Area \\
\hline As & - Alr Semple Location & \multicolumn{2}{|c|}{ UM - Undarground Radionctive Materiais Area } \\
\hline \multicolumn{4}{|c|}{$\begin{array}{l}\text { Defaule units are in mR/hr and are for open window betalgamma readings. Letter suffixes with the number } \\
\text { indicate specific radlations: B - Beta (mRad/hr), G-Gamma (mRhr), } N \text { - Neutron (mRem/hr). Boundary } \\
\text { designations are looking from the designatlons into the zoned area. }\end{array}$} \\
\hline
\end{tabular}


ORNL Radiological Survey Data Survey Number: $3038-94-0163$

3038 Field Office Date: 11] 3/94 Time: 1020

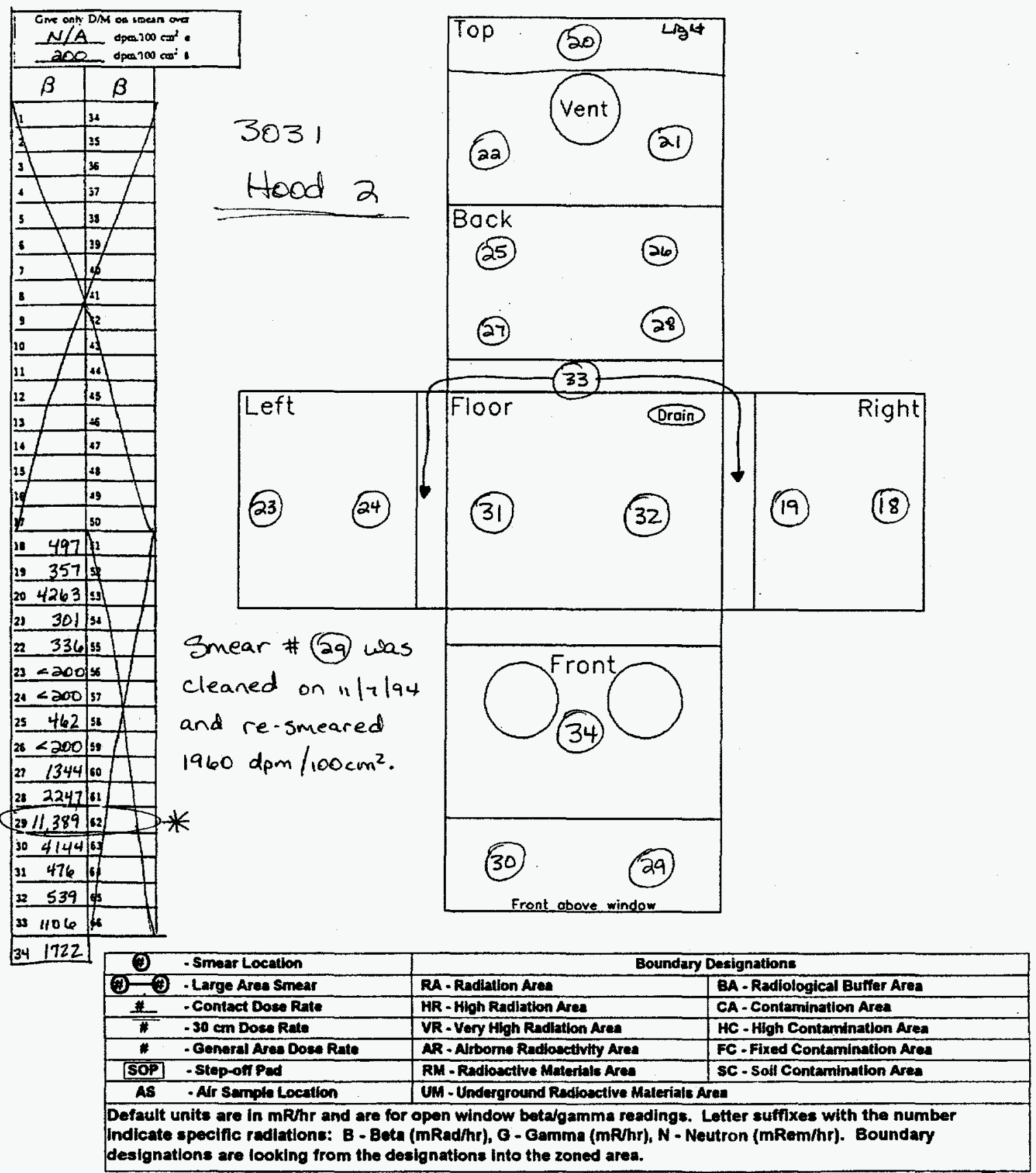




\section{ORNL Radiological Survey Data 3038 Field Office Dale: 11/3/94 Time: 1020} Survey Number: $3028-48-0163$
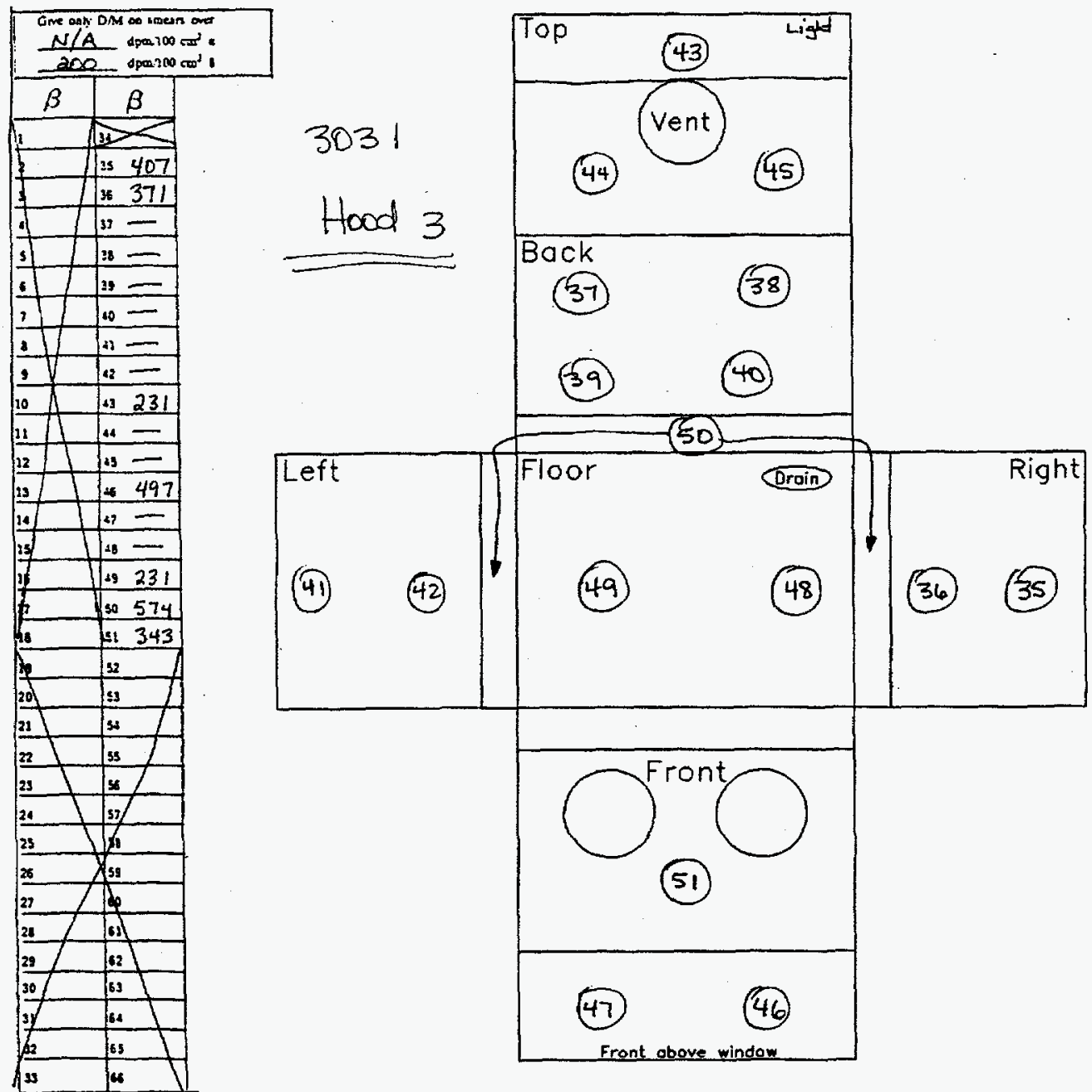

\begin{tabular}{|c|c|}
\hline 3 & - Smear Location \\
\hline 97 & - Large Area smear \\
\hline il & - Contact Dose Rate \\
\hline$\overline{10}$ & - 39 cm Dose Rate \\
\hline 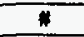 & - Genural Ares Dose Rato \\
\hline SOP & - step-oif Ped \\
\hline As & - Alir Sampla Location \\
\hline
\end{tabular}

RA-Radiation Ares HR - Hha Radiation Ares

VR - Very High Redlation Aree

AR - Altrome Radlosctivity Area

RM - Radiosetive Materials Aves

UM - Underground Radioactive Materials Are

Boundary Designation:

Defaut units are in $\mathrm{mRhr}$ and are for open window betagamma readings. Letter sutfixes with the number indicate specific radiations: B - Beta (mRad/hr), O - Gamma (mR/hr), N-Neutron (rnRem/hr). Boundary

designations are looking from the designations into the zoned area. 
ORNL Radiological Survey Data Deberafhchossno survey Number: $30,38-96-1882$ 3034 Fheld onice Date: $8-26-96$ Thwe: 0950

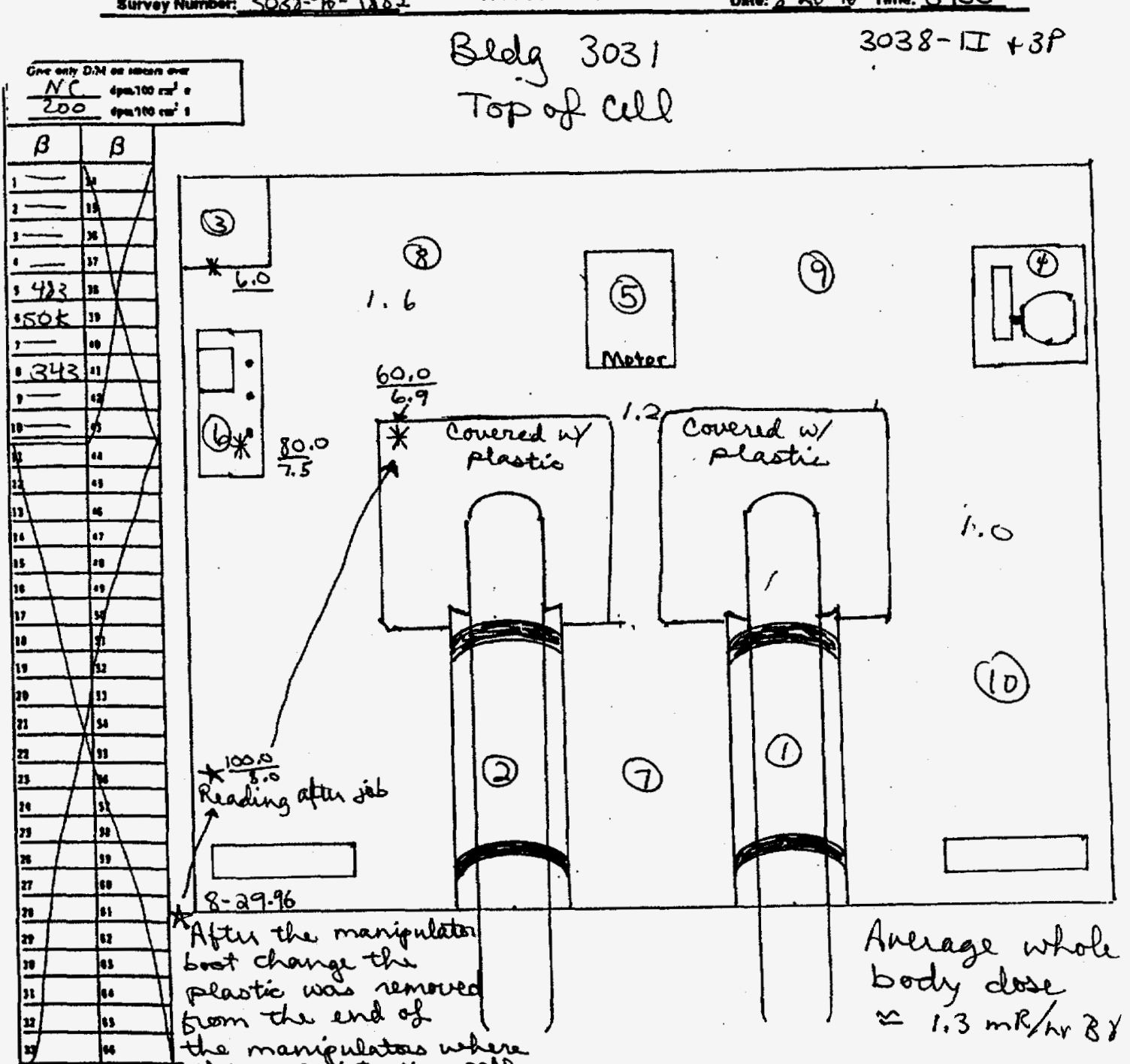

the manipulatas where

\begin{tabular}{|c|c|c|c|}
\hline 7 & - Smeer Loention & \multicolumn{2}{|c|}{ Boundery Denlensallone } \\
\hline 7 & - Lupe Anea enom & PA-Rediation Area & 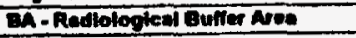 \\
\hline 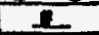 & - Contret Doce Rete & MT-Fon fedintion Area & CA.Contanimillon Aved \\
\hline$\pi$ & -3 tem oben Rete & Yh-Very firen necletion ares & We - Miph Contendantion Aree \\
\hline 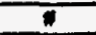 & - Oenerell Area Dose kele & 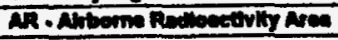 & FC - Flued Cominnination Nrea \\
\hline $50^{\circ}$ & - Sloponpas & RM - Reviogethe Mnumicle Ares & 86-8oll Contenimution Aren \\
\hline A & - Ar senpie Lucetion & \multicolumn{2}{|c|}{ UM - Lnderpoend Rerlonethe Meteribla Ares } \\
\hline & & 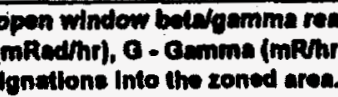 & $\begin{array}{l}\text { ter zunfer with the number } \\
\text { ron (mRem/hr). Boundery }\end{array}$ \\
\hline
\end{tabular}

\#Q2 Probed with portable inst. It was covered with Pag: 2 plastic afan survey. The top of the cell was posted as a contamination area 


\section{ORNL Radiological Survey Data}

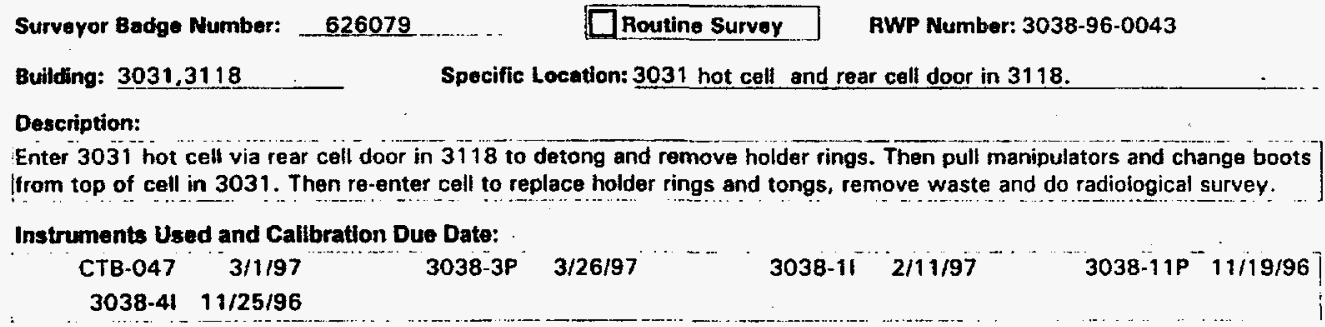

General Description of Rediological Conditions: Previous suruey

Maximum loose contamination: $15 \mathrm{mR} / \mathrm{hr} / 100 \mathrm{~cm}$ sq beta-gamma inside cell, on top of cell $50,000 \mathrm{dpm} / 100 \mathrm{~cm}$ sq betagamma. Maximum fixed contamination: Inside cell $1 \mathrm{R} / \mathrm{hr}$ with a average whole body dose of $35.0 \mathrm{mR} / \mathrm{hr}$ beta-gamma. On top of cell $80.0 \mathrm{mr} / \mathrm{hr}$ beta-gamma. The highest in cell smear from survey performed $8 / 29 / 96$ was $4.5 \mathrm{mR} / \mathrm{hr}$ beta-gamma. The rest of the results are listed below. The post job survey of the room revealed loose contamination on the plastic icovering the floor around the cell up to $420 \mathrm{dpm} / 100 \mathrm{~cm}$ sq beta-gamma. The plastic was removed and the whole room isurveyed all smears were $<200 \mathrm{dpm} / 100 \mathrm{~cm}$ sq beta-gamma and no detectable contamination on the large area masslin smears. It was posted as a fixed contamination area as it was previously except for the top of the cell.

Division or Group Meeding the Survey: CT Person-hours spent on the survey: 6

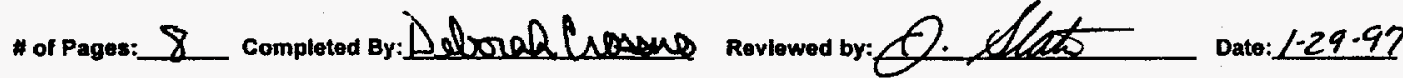

\begin{tabular}{|c|c|c|c|c|c|c|c|c|c|c|c|}
\hline & & & Smea & Result & (dpm) & $1100 \mathrm{~cm}^{2}$ & unles & loted) & & & \\
\hline $\begin{array}{c}\text { Smaer } \\
\text { Number }\end{array}$ & $\alpha$ & $\beta$ & Lacation & {$\left[\begin{array}{c}\text { Simear } \\
\text { Number }\end{array}\right.$} & $\alpha$ & $\beta$ & Loeation & {$\left[\begin{array}{c}\text { sinew } \\
\text { Number }\end{array}\right]$} & $\alpha$ & $\beta$ & Locstion \\
\hline & NC & 100,000 & 000 & 2 & $\mathrm{NC}$ & 140,000 & Soen mose & 3 & $\mathbf{N C}$ & 70,000 & 800 mon \\
\hline & NC & 90,000 & How mas & & NC: & $4.5 \mathrm{mR} / \mathrm{hr}$ & soo mop & 6 & $\mathrm{NC}$ & 200,000 & 500 mopo \\
\hline & $\mathrm{NC}$ & 2,884 & men & & NC & 6,300 & ton mop & 9 & NC & 1,533 & See nep \\
\hline 10 & NC & 6.482 & oinges & 11 & NCS & $2.8 \mathrm{mRMhr}$ & soos mep & 12 & $\mathrm{NC}$ & 2,681 & Seen mens \\
\hline
\end{tabular}

Description Manipulater pult.

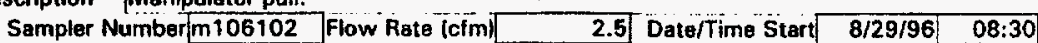

\begin{tabular}{lllll}
\hline & Filter Efficiency $100.0 \%$ & Date/Time End $8 / 29 / 96$ & $13: 30$ \\
\hline
\end{tabular}

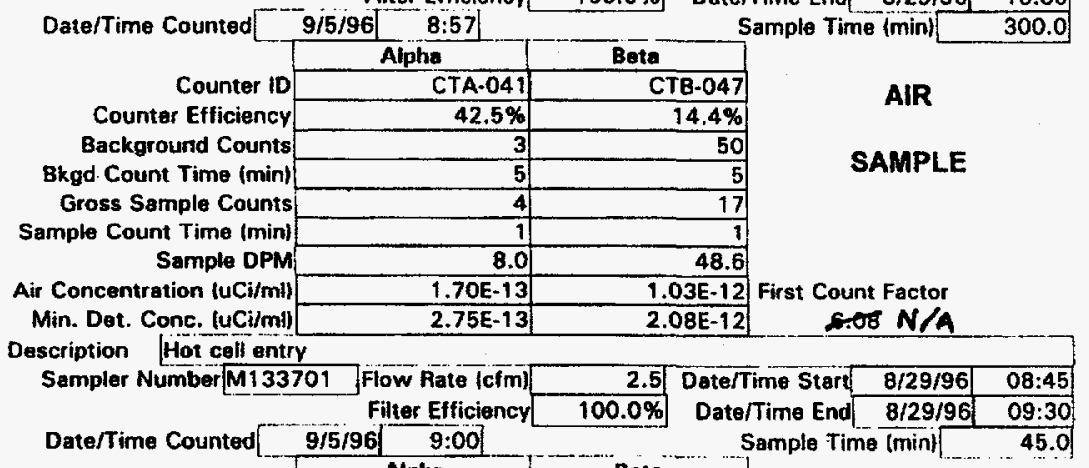

Counter ID

Counter Efficiency

Background Counts

Bkgd Count Time Imin

Gross Sample Count

Sample Count Time (min)

Sampla DPM

Air Concentration (uCi/mi) 9:0

Semple Time $(\mathrm{min})$

AIR

SAMPLE

Min. Det. Conc. (uCi/ml)

CTA-041

$42.5 \%$

CTB-047

$14.4 \%$

\begin{tabular}{r|r|}
4 & 50 \\
\hline 5 & 5 \\
\hline
\end{tabular}

\begin{tabular}{r|r|}
\hline 1 & 1 \\
\hline 12.2 & 4888.9 \\
\hline $1.73 \mathrm{E}-12$ & $6.91 \mathrm{E}-10$ \\
\hline
\end{tabular}

First Count Factor

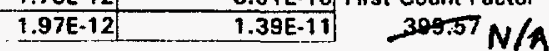



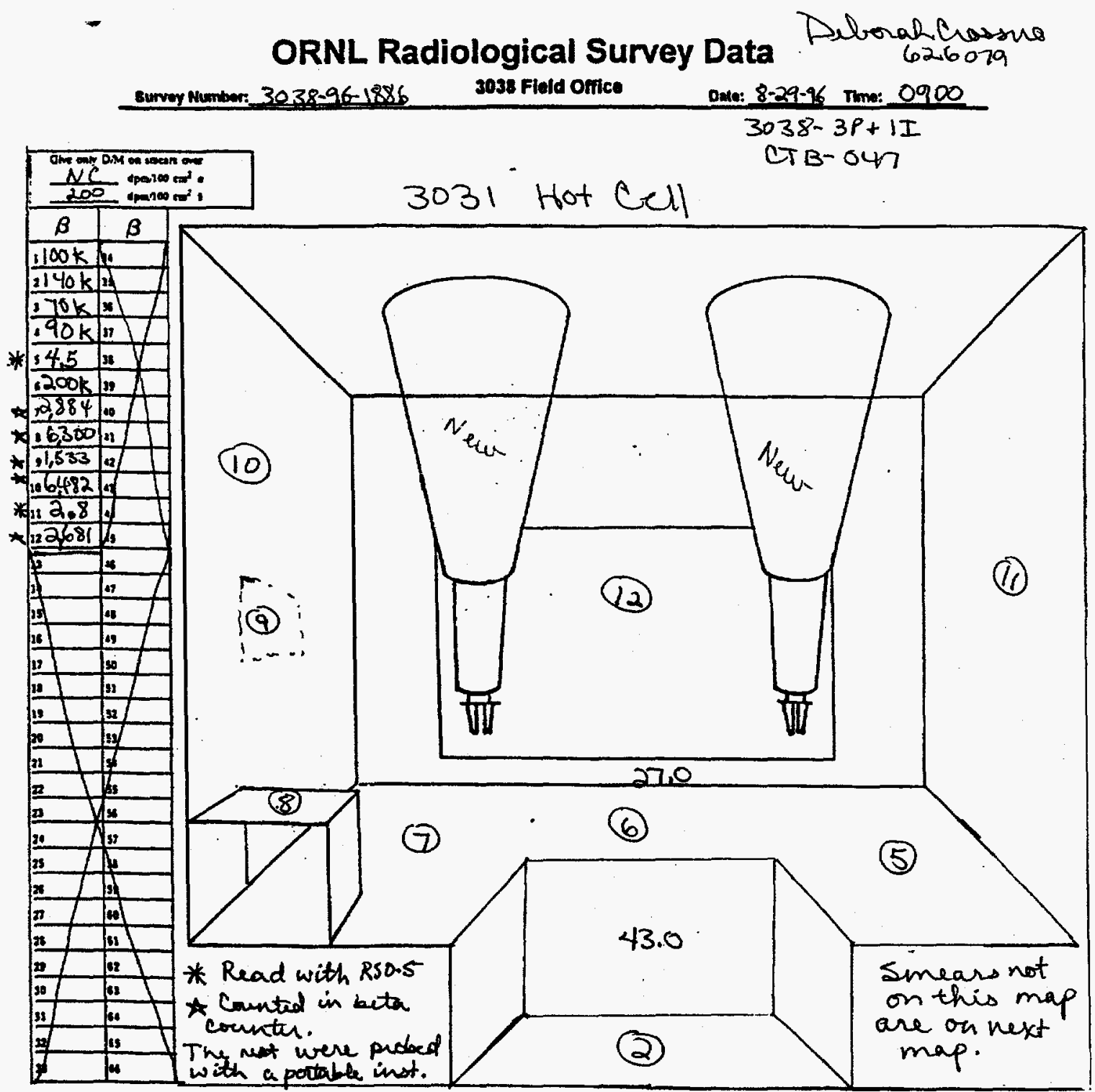

\begin{tabular}{|c|c|c|c|}
\hline$(3)$ & - Enver Locention & \multicolumn{2}{|c|}{ Bovendary Destenetions } \\
\hline 3 & - Lrove Area Eminar & RA-Rodietion Are & BA - Radiologlcal Buffer Area \\
\hline I & - Conted Dose Rate & Fin - Riligh Radiation Area & CA - Conteminatlon Ares \\
\hline$\pi$ & $-30 \mathrm{em}$ Dose Rate & VR-Ver fllon Radiedion Ases & Ac - Hoh Cornamination Aree \\
\hline 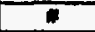 & - Generel Ares bose fate & M-Ahorme Redionethity Ares & FC-Fixed Consemination Ares \\
\hline$[0]$ & - step-oft Ped & 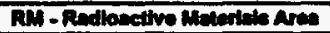 & sc - Soll Contumination Area \\
\hline As & - Ar empla Locintion & \multicolumn{2}{|c|}{ Uii - Undervound Redionet tre Matertals Ares } \\
\hline \multicolumn{4}{|c|}{ 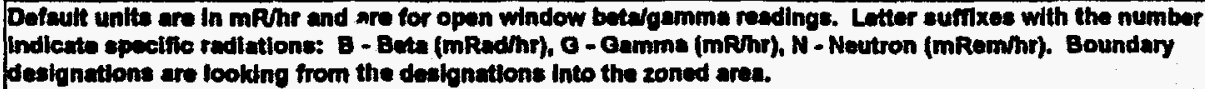 } \\
\hline
\end{tabular}

Average whale body dose $\approx 35.0 \mathrm{mR} / \mathrm{hr} \mathrm{Br}$ Papo 5 


\section{ORNL Radiological Survey Data 626079 3038 Field Office Dato: 8-29.96 Timo: 0900} survey Numbar: $3038-96-1886$

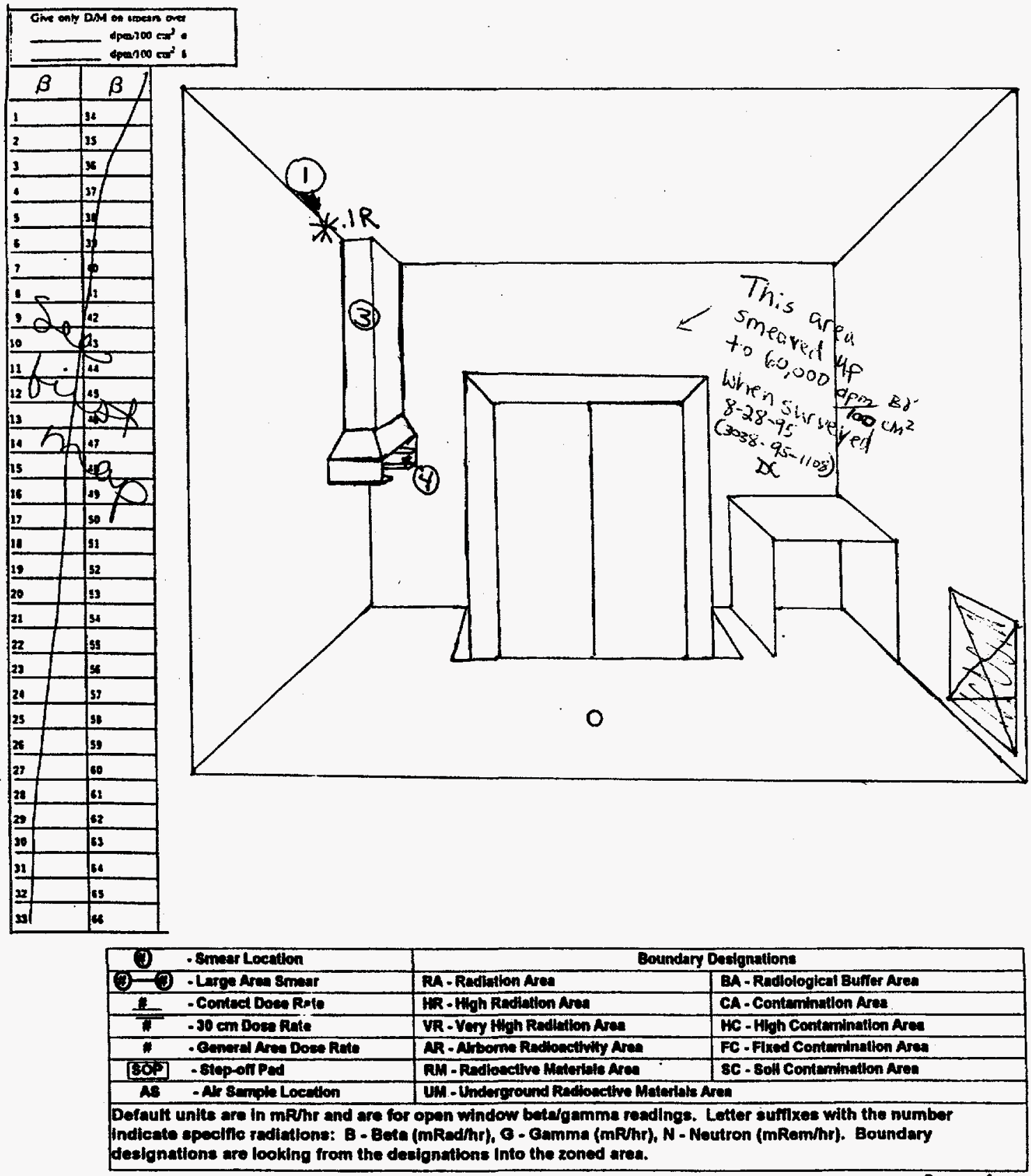




\section{ORNL Radiological Survey Data}

Bullding: 3031

Specific Location: Roof

Description:

Bi-annual radiation survey.

Instruments Used and Calibration Due Date:

$$
\text { 3038-41 11/25/96 }
$$

General Description of Radiological Conditions:

The average whole body dose is $-0.46 \mathrm{mR} / \mathrm{hr}$ beta-gamma. The highest background reading is $1.3 \mathrm{mR} / \mathrm{hr}$ beta-gamma and is on the side of the roof near fbuilding 3029 . The fitter bank is reading about the same as the background.

Division or Group Needing the Survey: CT

Person-hours spent on the survey:

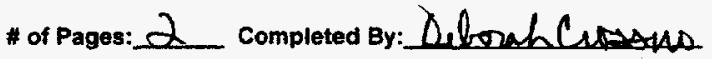

Revlewed by:

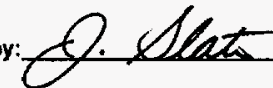

Date: $8-20-96$ 


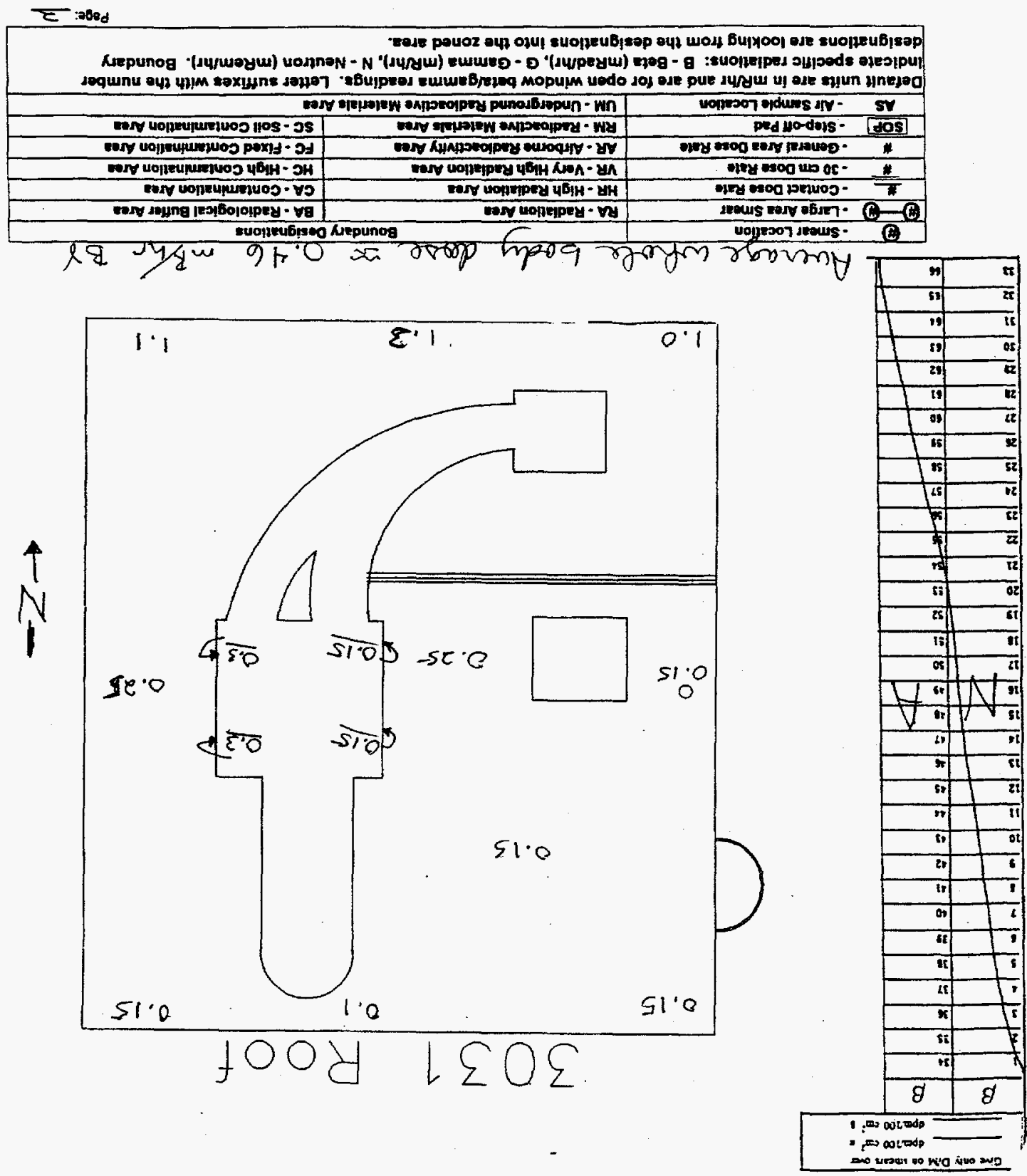

It $-8 \varepsilon \circ \varepsilon$

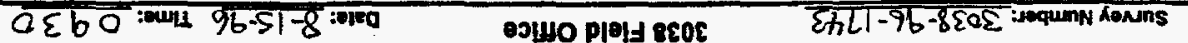

blogrg efeo Kanuns jeọbolo!pey רNYO

mmann Mminity 


\section{ORNL Radiological Survey Data}

Surveyor Badge Number: $\quad 34657$

Bullding: 3031

Specific Locetion: Attic

Description:

Radiation and Contamination Survoy.

Instruments Used and Callbration Due Date:

$\begin{array}{lll}\text { CTA-041 2/20/96 } & \text { CTB-047 }\end{array}$

$2 / 20 / 96$ $3038-11$ $1 / 29 / 95$

General Description of Radiological Conditions:

Thirty Dofensap Smears were taken in the attic of building 3031 on this date. All smears were found to be $<20 \mathrm{dpm} / 100$ $\mathrm{cm}^{-2}$, alpha and $<200 \mathrm{dpm} / 100 \mathrm{~cm}^{-2}$ beta-gamma. General area dose rangad from $0.1 \mathrm{mR} / \mathrm{hr}$ to $0.5 \mathrm{mR} / \mathrm{hr}$ near the old exhaust vents that went to the coll in building 3031 .

Division or Group Needing the survey 2

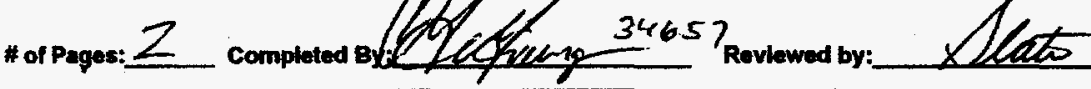
Date: $9.5-95$

\begin{tabular}{|c|c|c|c|c|c|c|c|c|c|c|c|}
\hline \multicolumn{12}{|c|}{ Smear Results (dpm/100 cm unless noted) } \\
\hline \begin{tabular}{|l|} 
Smear \\
Number \\
\end{tabular} & $\boldsymbol{\alpha}$ & $\boldsymbol{\beta}$ & Locention & $\begin{array}{l}\text { Soviar } \\
\text { Number }\end{array}$ & $\alpha$ & $\boldsymbol{\beta}$ & Locauten & \begin{tabular}{|l|l|} 
Smmoer \\
Number \\
\end{tabular} & $\alpha$ & $\mathbf{\beta}$ & Locention \\
\hline 130 & & & $=00000$ & & & & & & & & \\
\hline
\end{tabular}




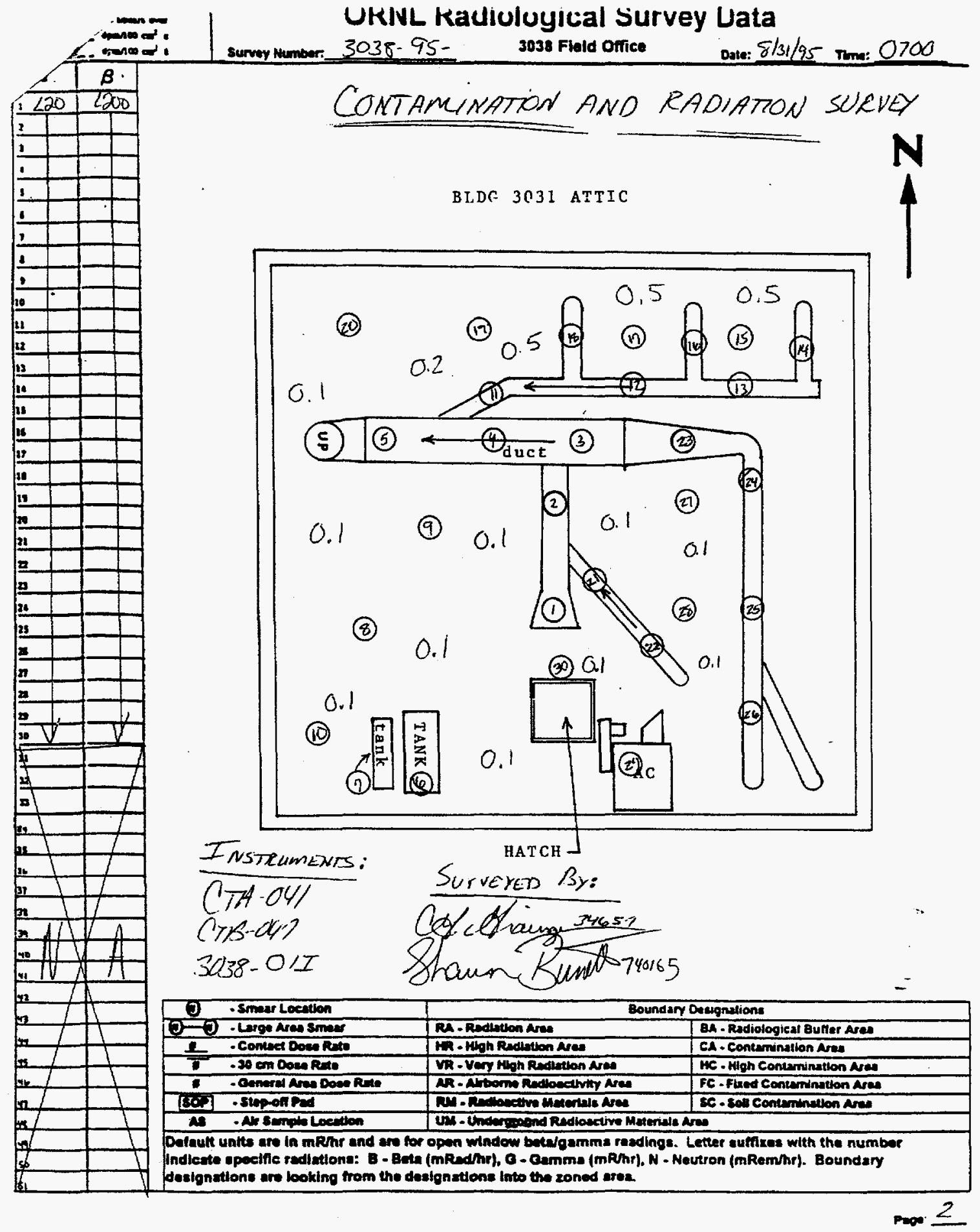




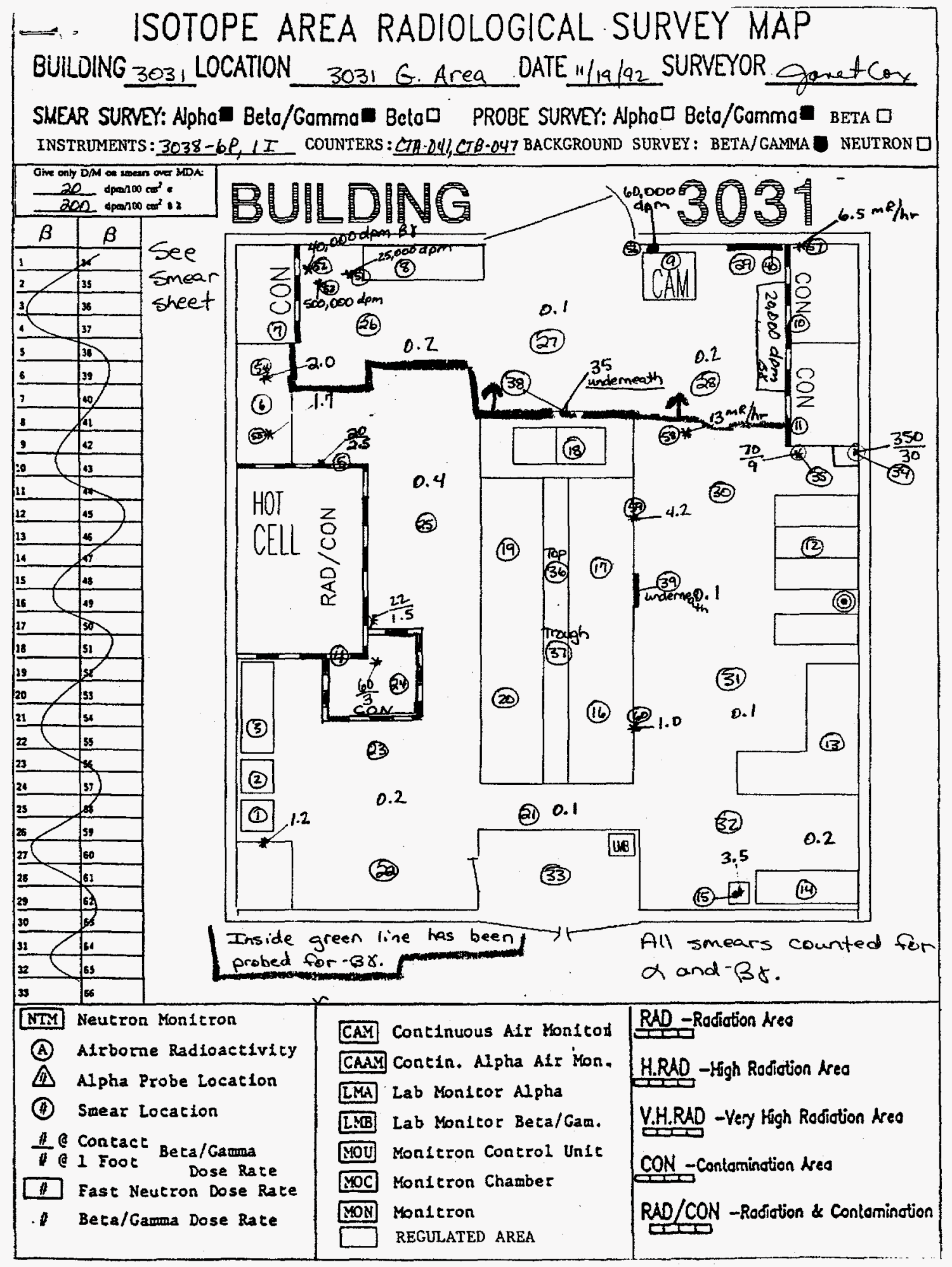


SMEAR SAMPLE DATA

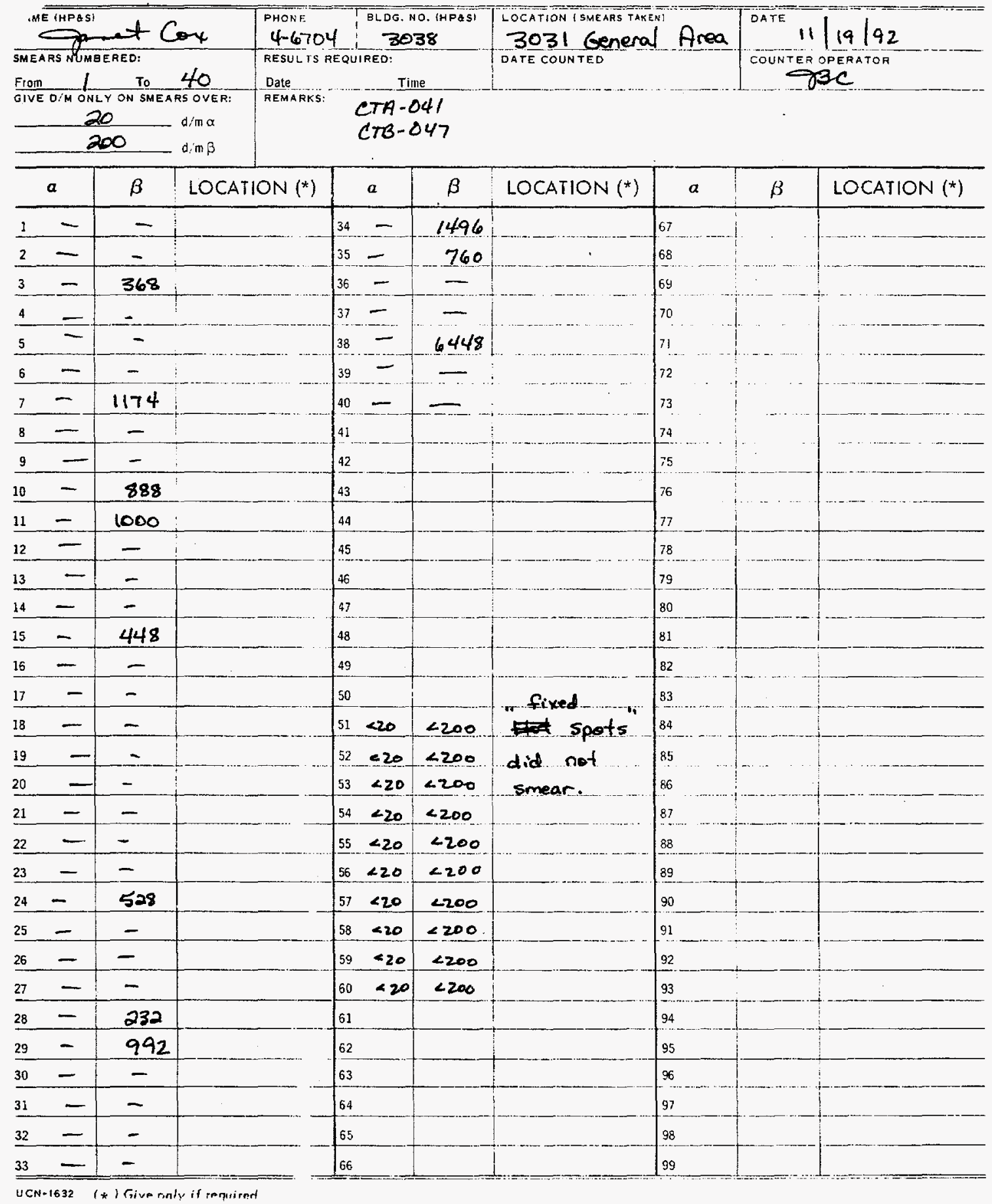




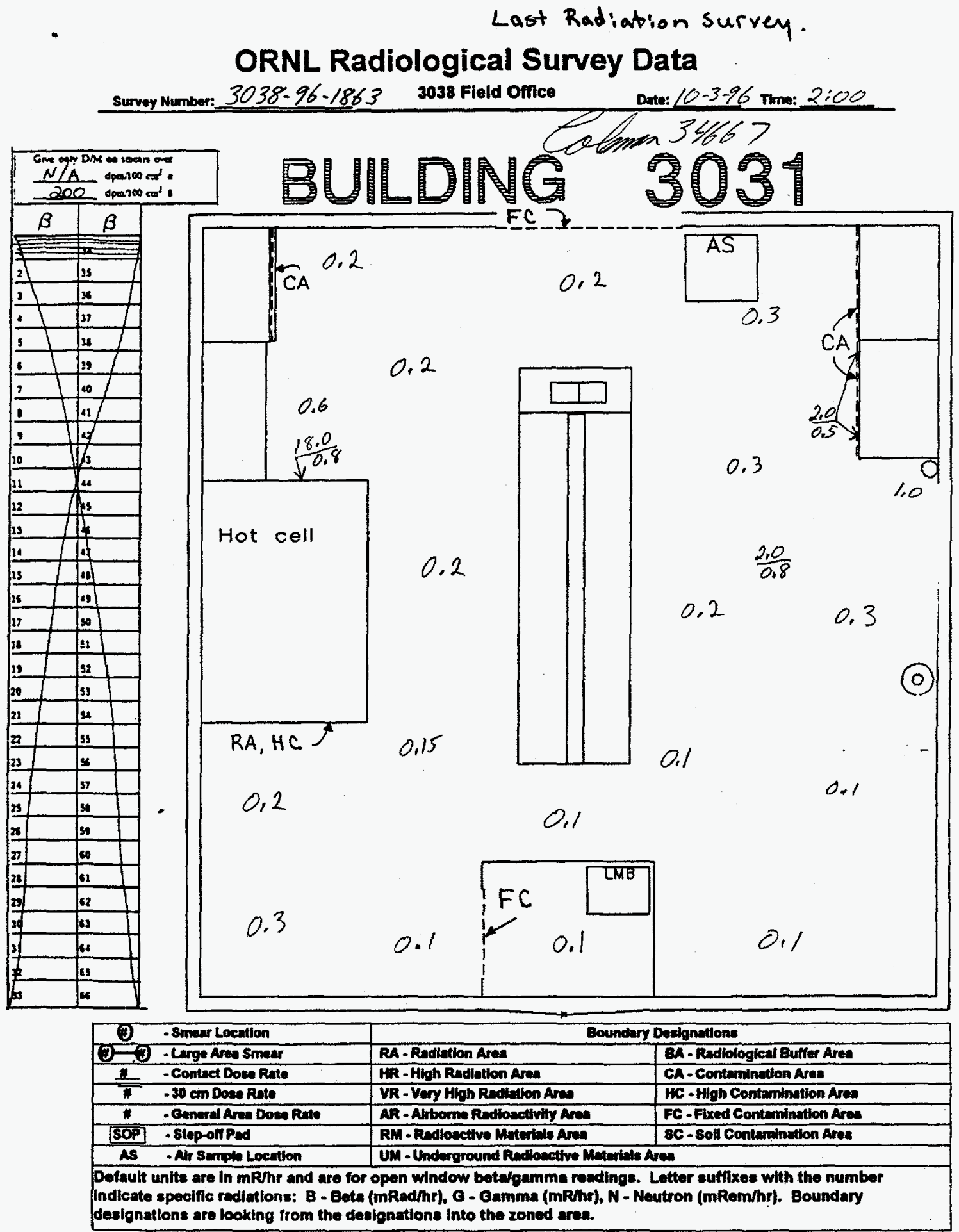

Guerag Whole Body Dose Rate $0.25 \mathrm{mRam}$ thr. 


\section{Last contamination Deborah hassno \\ ORNL Radiological Survey Data 626079} survey Number: $3038-97$-0j44 3038 Fleld Omce oute: 22197 Trme: 12,5

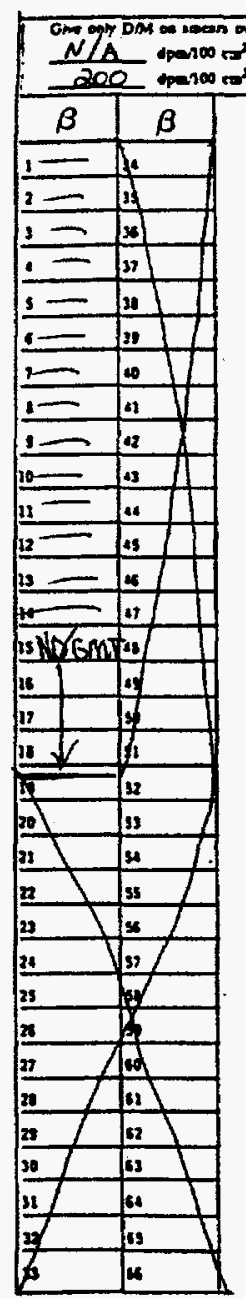

\section{BUILDING}

3031

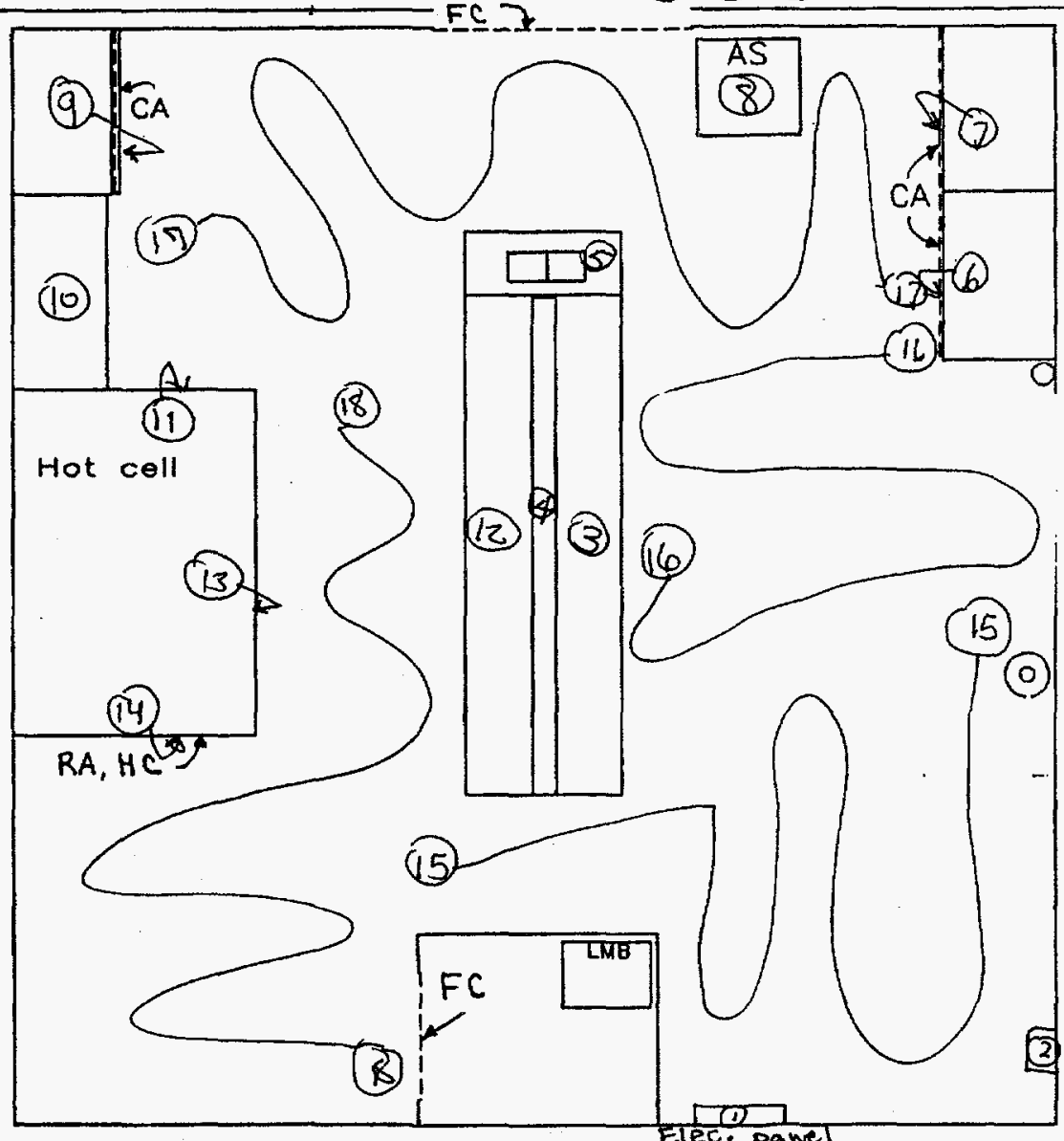




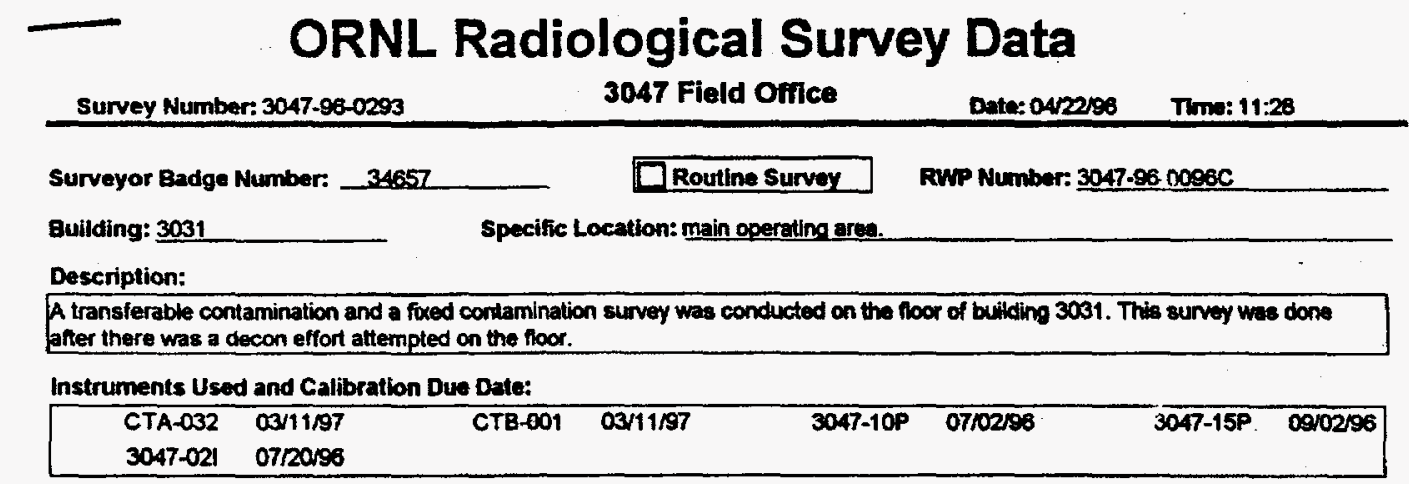

General Description of Radiological Conditions:

Transferable contamination up to $9,800 \mathrm{dpm} / 100 \mathrm{~cm} / 2$ beta-gamma was found. Fbeed contamination up to $15 \mathrm{mr} / \mathrm{hr}$ was detected on the floor in building 3031. Please see map(s) for more detailod information on fheded and transierable contamination.

Division or Group Needing the Survey: for Person-hours spent on the survey:

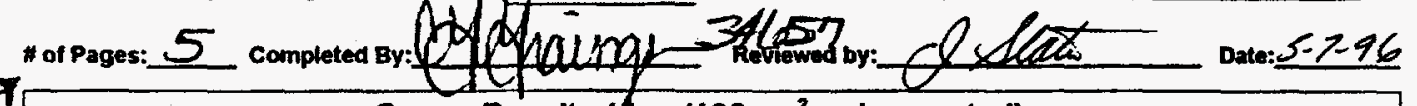

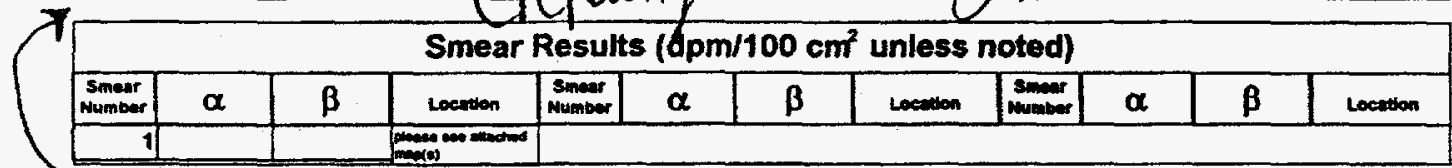

RWP+ Sign-in sheets

not included with this

copy. 


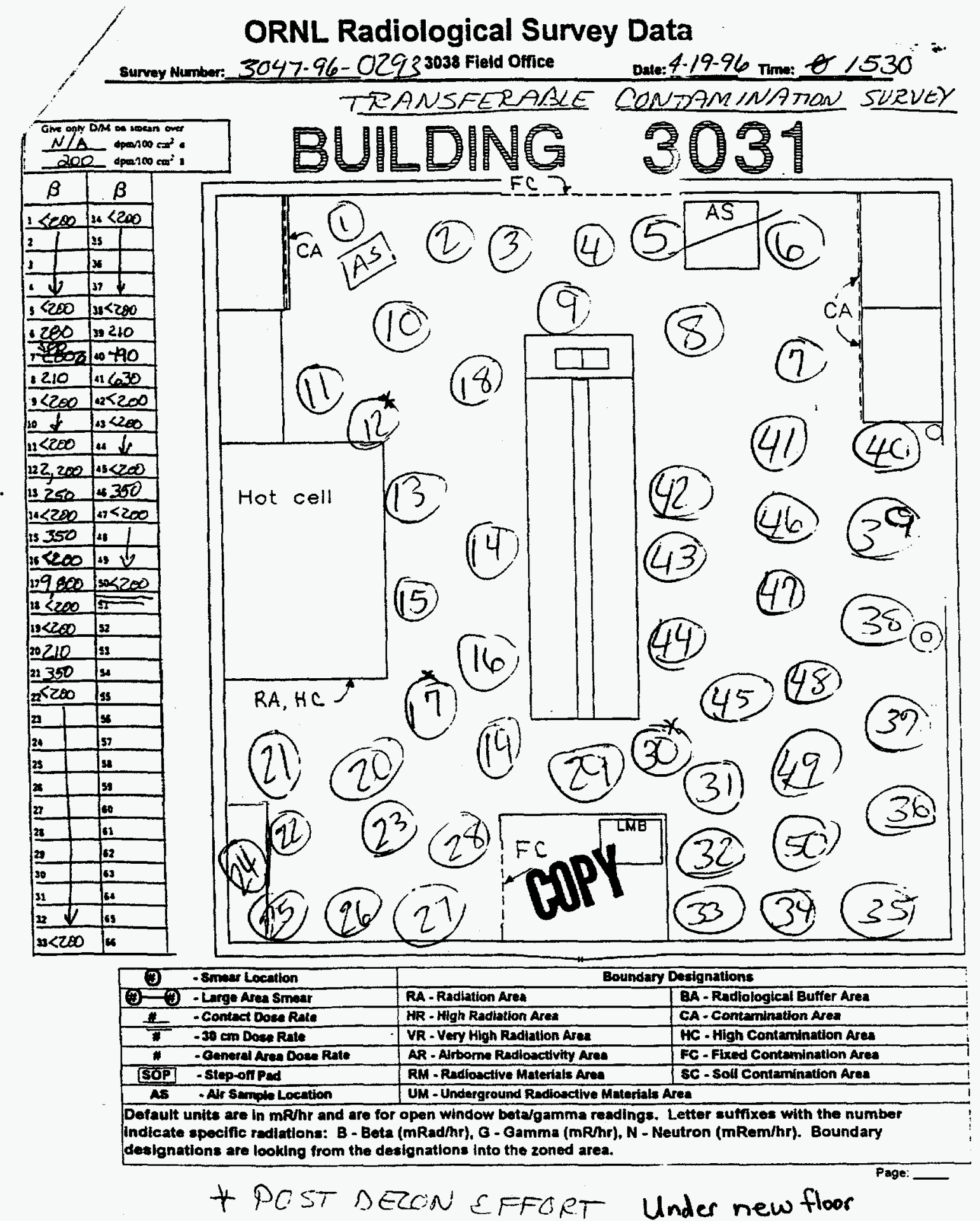


ORNL Radiological Survey Data

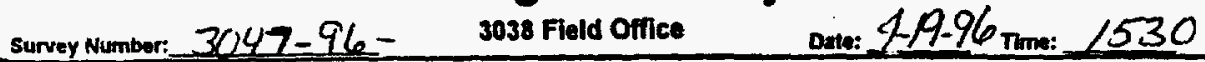
FIXED CONTAMINATION SURVEY

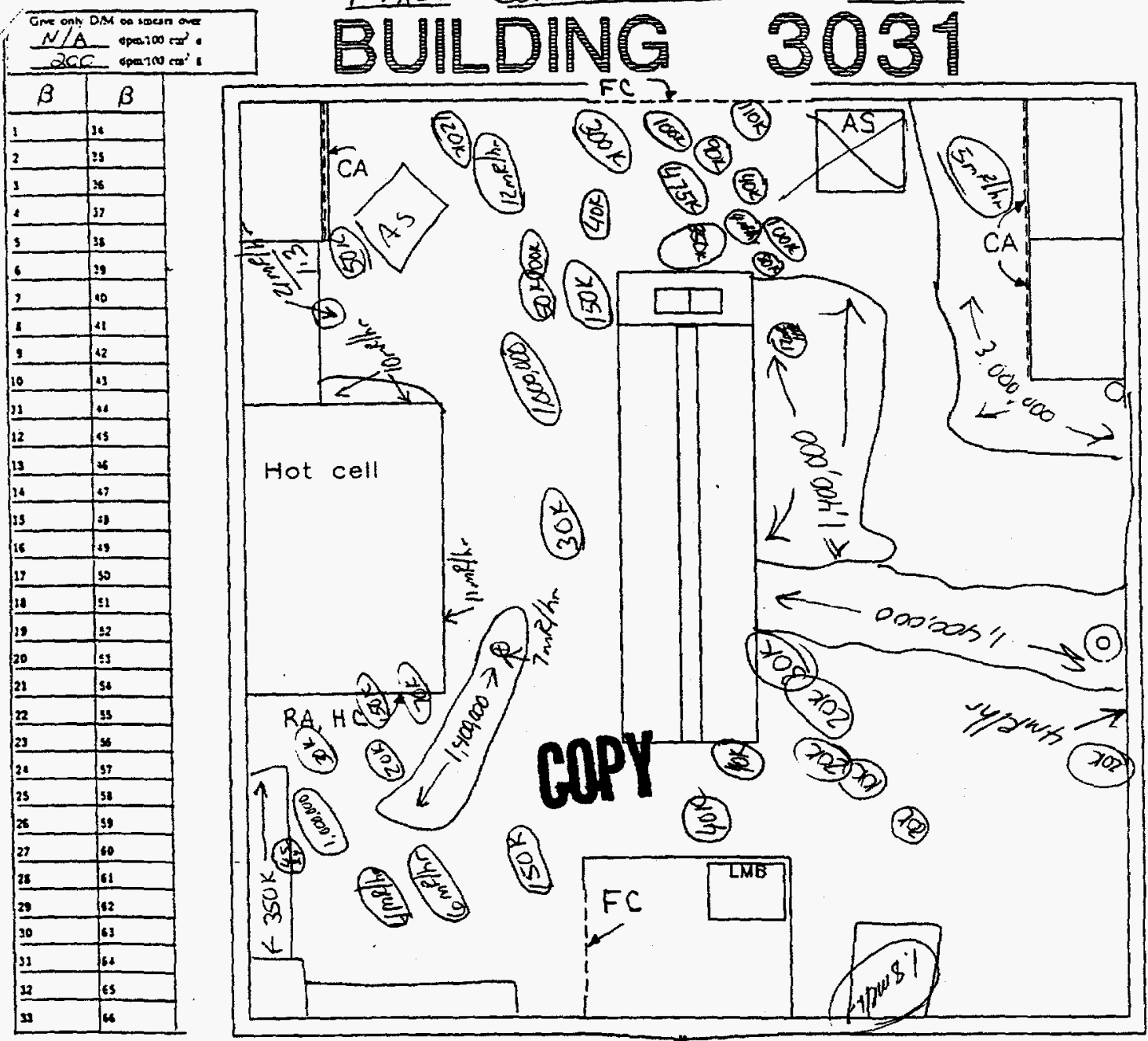

\begin{tabular}{|c|c|c|c|}
\hline (5) & - Smear Location & \multicolumn{2}{|c|}{ Boundary Designations } \\
\hline$\theta-7$ & - Large Ares Smear & RA-Radiation Area & BA - Radiological Buffer Area \\
\hline il & - Contact Dose Rate & HR - High Radlation Ares & CA-Centamination Area \\
\hline 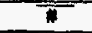 & $.30 \mathrm{~cm}$ Dose Rate & VR - Very High Radiation Ara & HC - High Contaminatlon Area \\
\hline * & - General Avea Dose Rate & AR - Albooms Radionetivity Area & FC - Fred Contamination Ares \\
\hline SOP & - Step-on Pad & RM - Redlosetive Materials Area & SC - Soll Contamination Ares \\
\hline As & - Ar sample Location & \multicolumn{2}{|c|}{ UM - Underground Rediancthe Materials Area } \\
\hline \multicolumn{4}{|c|}{ 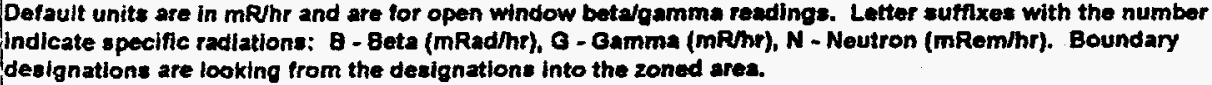 } \\
\hline
\end{tabular}
* POST DECON EFFORT under new floor 



\section{DISTRIBUTION}

1. L. V. Asplund

2. W. D. Brickeen

3. R. A. Brown

4. T. W. Burwinkle

5. K. Constant

6-15. R. E. Eversole

17. K. W. Haff

18. S. A. Herron

19. L. L. Kaiser

20. T. M. Koepp

21. P. T. Owen

22. L. D. Owens

23. B. D. Patton

24. L. B. Raulston

25. Central Research Library

26. File-EMEF DMC-RC 
